\title{
RELIGIÃO E POLÍTICA NAS ELEIÇÕES 2000 EM PORTO ALEGRE (RS)*
}

\author{
Ari Pedro Oro \\ Professor de Antropologia da Universidade \\ Federal do Rio Grande do Sul
}

\section{Resumo}

Este texto versa sobre as articulações entre religião e política nas eleições proporcionais do ano 2000 realizadas na cidade de Porto Alegre, capital do Estado do Rio Grande do Sul. Este tema será desenvolvido em quatro pontos. No primeiro será visto como o religioso se insere no político, e vice-versa, durante a campanha eleitoral para o executivo municipal. Na sequência será efetuada uma análise do discurso de 17 candidatos religiosos à Câmara Municipal. Em terceiro lugar, ver-se-á como o êxito ou o fracasso eleitoral dos candidatos religiosos tem diretamente a ver com a estrutura organizacional das religiões às quais eles estão vinculados; enfim, analisar-se-á como, no segundo turno das eleições, o tema da ética na política aproximou a Igreja Universal do Reino de Deus e o Partido dos Trabalhadores.

\section{Durante as eleições realizadas em Porto Alegre, em outubro de $2000^{1}$, o religioso compareceu na campanha eleitoral para o executivo}

\footnotetext{
* Este texto resulta de uma pesquisa apoiada pelo CNPq.

${ }^{1}$ Tratou-se de eleições proporcionais para o executivo e o legislativo dos municípios brasileiros. Realizaramse em 1 de outubro e em 29 de outubro para o segundo turno para prefeito nos municípios brasileiros que detém acima de 200 mil eleitores e onde nenhum candidato alcançou a maioria absoluta dos votos.

Por ocasião dessas eleições em Porto Alegre totalizava 966.799 eleitores. Nesta metrópole houve 11 candidatos a prefeito municipal e 411 candidatos disputaram as 33 cadeiras na Câmara Municipal. A eleição para prefeito foi decidida em segundo turno entre os candidatos Tarso Genro, da Frente Popular, e Alceu Collares, da Frente Ampla/Única, tendo sido vitorioso o primeiro, candidato do Partido dos Trabalhadores. Desta forma, o PT garantiu mais quatro anos à frente do executivo municipal, constituindose no quarto mandato consecutivo.

Os prefeitos anteriores foram Olívio Dutra (1989-1992), Tarso Genro (1993-1996) e Raul Pont (19972000).

As eleições municipais sempre tiveram uma grande importância na história do Brasil. No dizer de Moacir Palmeira:

"representam uma espécie de matriz para as demais. As eleições para cargos estaduais e federais tendem a funcionar nos municípios pequenos e médios (e aqui me parece funciona mais o tamanho do que o ser rural ou urbano) como uma forma de referendo das divisões sociais e da distribuição de poder operada pelas eleições municipais" (Palmeira, 2000:7).
} 
municipal e, principalmente, para o legislativo municipal. No primeiro caso, pôde-se observar que três importantes coligações que disputaram a prefeitura da capital gaúcha trouxeram o religioso para o campo político, embora, como veremos, em intensidade e circunstâncias diferentes entre si. No segundo caso, pôde-se ver que entre os 411 candidatos que disputaram uma das 33 cadeiras da Câmara Municipal, 17 deles eram agentes religiosos ${ }^{2}$.

O objetivo geral deste texto é analisar as articulações ocorridas entre religião e política por ocasião das referidas eleições, em Porto Alegre. Argumento, nele, que a eficácia política alcançada por três agentes religiosos e o fracasso dos demais esteve, em grande medida, relacionada com a estrutura organizacional de cada religião/igreja às quais os candidatos estavam vinculados. Sugiro, também, no texto, que o discurso pela moralização da política aproximou a Igreja Universal do Reino de Deus (doravante Universal ou IURD) do Partido dos Trabalhadores (doravante PT) por ocasião da campanha do segundo turno para a prefeitura, constituindo-se isto num fato inédito já que até recentemente o PT era objeto de demonização por parte dessa Igreja (Freston, 1993).

O procedimento metodológico adotado para colher as informações necessárias à construção deste trabalho consistiu na realização de entrevistas com candidatos religiosos aos cargos eletivos ${ }^{3}$, entrevistas com líderes

\footnotetext{
${ }^{2}$ Por esta expressão refiro-me aos candidatos que reivindicaram abertamente a sua condição de líderes religiosos (membros da hierarquia ou participantes ativos de uma religião) ou que se apresentaram como representantes de uma organização religiosa.

Nesta condição encontram-se 17 candidatos, assim distribuídos: 3 da Universal, 4 da Assembléia de Deus, 1 da Igreja Quadrangular, 1 da Igreja Batista Filadélfia, 1 da Igreja Adventista do Sétimo Dia, 2 católicos (1 sacerdote e 1 leigo) e 4 pais-de-santo e 1 presidente de um centro religioso afro-brasileiro.

Houve, também, uma candidata evangélica a vice-prefeito pela Coligação União Trabalhista.

Convém salientar que embora em Porto Alegre não tenha havido uma significativa representação numérica de agentes religiosos na condição de candidatos no pleito eleitoral de 2000 , nele compareceram representantes dos principais segmentos religiosos que constituem o pluralismo religioso local, a saber: agentes religiosos católicos (padre, leigos engajados), evangélicos (pastores, evangelistas, obreiros) e mediúnicos (pais-de-santo). Vale lembrar, porem, que a diversidade religiosa porto-alegrense é mais ampla do que a mencionada, se levarmos em conta outros grupos religiosos aqui existentes, alguns deles vinculados a minorias étnicas, como judaísmo, budismo, islamismo, alem de "novos movimentos religiosos, tipo Nova Era.

${ }^{3}$ Foram entrevistados Sônia Santos, candidata a vice-prefeita pela coligação União Trabalhista, e os seguintes candidatos a vereador: Willis Taranger (da Assembléia de Deus), Jorge Verardi e Aureo Rodrigues (da Umbanda e Cultos Afro-Brasileiros) e João Carlos Nedel (igreja católica).

Agradeço às pessoas mencionadas pela contribuição prestada a esta pesquisa, bem como aos bolsistas PIBIC do Curso de Ciências Sociais da UFRGS Débora Leitão, Valdir Pedde e Marcio Santos, ao aluno do Curso de Ciências Sociais da mesma Universidade Richardson Luz e à aluna do Programa de PósGraduação em Antropologia Social da UFRGS Yvonete Campregher.
} 
de algumas expressões religiosas implicadas na política ${ }^{4}$, e, sobretudo, na análise do discurso dos candidatos religiosos, tal como foi veiculado durante o período da propaganda eleitoral gratuita na televisão ${ }^{5}$.

$\mathrm{Na}$ área da linguística, analise do discurso e analise de conteúdo constituem disciplinas que se aproximam e se distanciam ao mesmo tempo. Neste estudo, não seguirei à risca as orientações metodológicas inerentes à linguística. Análise do discurso e análise de conteúdo serão aqui vistas como complementares e utilizadas enquanto recursos úteis à análise antropológica do objeto sobre o qual versa este texto.

Recordo que análise de conteúdo consiste num conjunto de técnicas de análise cujo objetivo é compreender criticamente o sentido das comunicações, percebendo o seu conteúdo escondido, latente, não aparente (Bardin, 1977). Há, na atualidade, uma tendência, embora controvertida, em análise de conteúdo, de se dar ao mesmo tempo um tratamento quantitativo e qualitativo para as mensagens, de se considerar as condições sociais da produção das mensagens e de se proceder a uma analise dos elementos constitutivos das mesmas visando uma categorização capaz de melhor compreender sua estrutura e intencionalidade. Para tanto, aspectos não-linguísticos (iconográficos, por exemplo) e linguísticos (escritos e orais) são igualmente levados em consideração (Richardson, 1999).

Por sua vez, a análise do discurso "situa seu objeto - o discurso - no campo das relações entre o linguístico e o histórico-ideológico, buscando, no interior deste campo, as determinações sociais, políticas e culturais dos processos de construção do sentido" (Mariani, 1999:107). Ou seja, a analise do discurso transcende a análise linguística do texto em si e visa articular a enunciação discursiva sobre um certo lugar social (Maingueneau, 2000:13).

\footnotetext{
${ }^{4}$ Refiro-me ao pastor João Ferreira Filho, Presidente da Igreja Assembléia de Deus do Rio Grande do Sul, o pastor Vice-Presidente da mesma igreja, e Adalberto Pernambuco Nogueira, presidente do CEUCAB (Conselho Superior dos Cultos Afro-Brasileiros).

${ }^{5}$ Por ocasião do primeiro turno das eleições, o horário eleitoral gratuito se estendeu de 15 de agosto até 28 de setembro de 2000; no segundo turno, de 16 a 27 de outubro.

Foi efetuada a gravação de todos os programas veiculados durante este período eleitoral e posteriormente analisados.
} 
Para os propósitos deste trabalho, retenho, das colocações acima, os seguintes elementos: a importância da apropriação das exterioridades do discurso para alem dos aspectos linguísticos em si, orais ou escritos (ou seja, a apresentação pessoal dos candidatos no vídeo, símbolos e imagens utilizadas); a constituição de um corpus discursivo (isto é, o discurso de agentes religiosos institucionais durante o programa eleitoral gratuito na televisão); e a constituição de unidades temáticas discursivas (a saber: a auto-apresentação dos candidatos, sua história, suas propostas e sua afinidade religiosa).

O conceito de carisma será uma importante ferramenta analítica neste texto. Este termo, como se sabe, foi amplamente elaborado por M. Weber, para quem carisma é uma qualidade extraordinária, de caráter extra-quotidiano - reconhecida como tal por um grupo social - que caracteriza alguns indivíduos (profetas, feiticeiros, chefes militares, "demagogos"), detentores de um carisma pessoal, mas também instituições do tipo igreja, portadoras de um carisma de função, ou de instituição, derivado da apropriação de um carisma pessoal fundador (profético), rotinizado (Weber, 1971:249) ${ }^{6}$. A relação entre carisma pessoal e graça institucional, diz Bourdieu, é de luta pelo monopólio do exercício legítimo do poder religioso. Ou seja, a igreja, enquanto empresa burocrática de salvação ${ }^{7}$, "é incondicionalmente hostil ao carisma "pessoal”, isto é, profético, místico ou extático, que pretende indicar um caminho original em direção a Deus" (Bourdieu, 1987:95). Ao mesmo tempo, a igreja preconiza que seus funcionários (padres ou pastores) “deve(m) se subordinar à graça institucional sob pena de condenação..."

\footnotetext{
${ }^{6}$ Segundo J. Séguy, "para Weber o carisma de função representa uma derivação institucional do carisma pessoal quando este se rotiniza e assume, no processo, significações e funções novas. O carisma pessoal, por sua vez, caracteriza o profeta (no domínio religioso), ou o "demagogo" (no domínio político), ou ainda o chefe de guerra de qualidades excepcionais (no campo militar)" (Séguy, 1988:14-15).

${ }^{7}$ Para Bourdieu, "a Igreja apresenta inúmeras características de uma burocracia (delimitação explícita das áreas de competência e hierarquização regulamentada das funções, com a racionalização correlata das remunerações, das "nomeações", das "promoções" e das "carreiras", codificação das regras que regem a atividade profissional e a vida extraprofissional, racionalização dos instrumentos de trabalho, como o dogma e a liturgia, e da formação profissional etc)" (Bourdieu, 1987:59-60).
} 
(Séguy, 1982:33); eles devem reproduzir as obrigações articuladas pela instituição proprietária do carisma de função (Id. Ibid.:40).

Consequentemente, afirma Séguy,

"o carisma, na origem qualidade altamente pessoal, instável, efêmera e, por definição, intransmissível, torna-se transmissível, estável e durável, independentemente - ao menos no limite - das qualidades pessoais de seu detentor. Este último - obviamente - se propõe a reproduzir a mensagem e as exigências da instituição na qual e para a qual exerce sua função (na qual ele é, neste sentido, funcionário)" (Séguy, 1988:18).

Mas, pondera ainda J. Séguy,

“o carisma de função não se resume na imposição arbitrária a um indivíduo de uma ocupação específica por uma organização do tipo legal-burocrática; o carisma de função supõe a aquisição do que P. Bourdieu chama de habitus; este não resulta de uma decisão a priori, ou de uma simples manipulação ritual; ele está ligado a um fenômeno desta sorte mas somente após submeter os candidatos a prova: esta é destinada a fazer aparecer e a separar aqueles que aos olhos dos dispensadores exclusivos do carisma de função possuem de forma inata - ou suposta - o germe do habitus..." (Séguy, 1982:49).

\section{I - Política e Religião na campanha para o executivo municipal}

Como já disse acima, houve em Porto Alegre 11 candidaturas para a prefeitura municipal, sendo 7 coligações e 4 candidaturas exclusivas de um único partido, todos pequenos partidos.

A relação com a religião, em algum nível ao menos, se fez notar diretamente em três coligações: na Aliança Liberal Cristã - que reuniu três partidos (Partido da Frente Liberal, Partido Social Cristão e Partido Social Liberal) - por adotar a palavra Cristã na identificação da coligação; 
na União Trabalhista, formada por quatro partidos (Partido Democrático Trabalhista, Partido Trabalhista Brasileiro, Partido Trabalhista Nacional e Partido da Mobilização Nacional), por terem os candidatos a prefeito e a vice-prefeito algum vínculo religioso socialmente reconhecido; e na Frente Popular - encabeçada pelo Partido dos Trabalhadores e apoiada pelo Partido Comunista do Brasil, Partido Comunista Brasileiro e pelo Partido Socialista Brasileiro - por recorrer ou aceitar o apoio explícito de líderes de diferentes religiões por ocasião da campanha do segundo turno eleitoral.

Quanto à primeira coligação mencionada, que teve Germano Bonow e Frederico Domingues Barbosa, ambos do PFL, concorrendo para prefeito e vice-prefeito, respectivamente, embora tivessem concorrido pela Aliança Liberal Cristã, não foi possível identificar, em sua campanha televisiva, nenhuma menção direta e específica ao cristianismo. Ou seja, sua campanha não se distinguiu substancialmente da maioria das campanhas e dos temas tratados em época eleitoral por outros partidos e coligações, na medida em que enalteceram a necessidade de saúde, educação, transporte, segurança e melhores condições de vida para a população em geral. Não transpareceu nenhum apelo direto às crenças cristas, como não houve uma apropriação explícita e uso declarado do discurso religioso. No entanto, a escolha da palavra Cristã, ao lado de Aliança Liberal, como termos identificadores da coligação por certo não ocorreu isenta de intencionalidade. Alem de incorporar o Partido Social Cristão na coligação (um pequeno partido que apresentou somente 6 candidatos a vereador e que juntos não somaram 2.300 votos), o uso explícito do termo cristã certamente desejava acionar pre-noções, mitos, imagens, concepções religiosas que integram o universo simbólico dos eleitores - fruto da importância histórica que o cristianismo e, mais especificamente, o catolicismo detém na cultura brasileira - e assim marcar sua distintividade enquanto coligação que defende valores cristãos, supondo poder, desta forma, capitalizar votos (dos cristãos) para a coligação.

Obviamente, é impossível saber se este apelo político indireto ao cristianismo e seus valores surtiu efeito para a coligação liderada por 
Germano Bonow, uma vez que ela obteve somente $6,87 \%$ do total do sufrágio, classificando-se em quarto lugar no ranking eleitoral ${ }^{8}$.

A segunda coligação acima mencionada manteve relação com o campo religioso em razão sobretudo do fato de que tanto o candidato a prefeito (Alceu de Deus Collares) quanto a candidata a vice-prefeito (Sônia Santos) são conhecidos pelos seus vínculos religiosos, o primeiro com as religiões afro-brasileiras ${ }^{9}$ e a segunda com os evangélicos.

De fato, ao candidato a prefeito da referida coligação é socialmente atribuída a sua vinculação com as religiões afro-brasileiras, embora não consta ter havido uma tal identificação religiosa pública por parte do próprio candidato ${ }^{10}$. A atribuição social de sua relação com as religiões afro-brasileiras repousa tanto no fato de que se trata de um afrodescendente, que se reconhece como tal, quanto pelo fato de ser voz corrente no meio batuqueiro e popular gaúcho que Collares "é de religião", expressão aqui usada para quem é membro do batuque ou de outra forma religiosa afro-brasileira.

Mas, o vínculo, mais ou menos claro de Collares com as religiões afro-brasileiras, não the assegurou o apoio das federações de religiões afro-brasileiras de Porto Alegre ${ }^{11}$ ou dos terreiros e centros dessas religiões. Certamente alguns líderes e membros religiosos o apoiaram,

\footnotetext{
${ }^{8}$ Essa coligação apoiou, no segundo turno, a União Trabalhista, e juntas, associadas a outras coligações e partidos, formaram a Frente Única contra a Frente Popular.

${ }^{9}$ O Rio Grande do Sul constitui uma das principais regiões do Brasil em termos do número de centros e de frequentadores das religiões afro-brasileiras. Os dirigentes de federações de religiões afro-brasileiras de Porto Alegre afirmam que neste estado existem em torno de 30.000 terreiros.

${ }^{10} \mathrm{~A}$. Collares é um homem público de longa data tendo sido prefeito municipal, deputado federal por três vezes e governador do Estado. A sua relação com as religiões afro-brasileiras sempre aparece por ocasião das campanhas eleitoras sem, porém, ter o mesmo declarado publicamente essa pertença religiosa.

${ }^{11}$ As cinco maiores federações do Estado são as seguintes: Afro-Bras, Conselho Superior da Umbanda e dos Cultos Afro-Brasileiros (CEUCAB), Afro-Rito, Afro-Cone-Sul e União Espiritualista de Umbanda do Rio Grande do Sul.
}

Tais federações não parecem ter força política em Porto Alegre e no estado do Rio Grande do Sul como em outras regiões do Brasil, como em São Paulo e no Rio de Janeiro, por exemplo, onde membros das religiões afro-brasileiras tem obtido êxito em cargos políticos eletivos graças ao apoio das federações. Em Porto Alegre, como veremos mais à frente, nem mesmo o presidente da maior federação de religião afro-brasileira da capital e do Estado, não conseguiu votos suficientes para conquistar uma cadeira na Câmara Municipal de Porto Alegre. 
mas outros também apoiaram outros candidatos a prefeito, tendo havido nesta cidade, no âmbito dessas religiões, como veremos, uma profunda divisão de apoios políticos entre federações e líderes religiosos, tanto a nível do executivo quanto do legislativo municipal.

Por sua vez, a candidata a vice-prefeito da coligação União Trabalhista, Sônia Santos ${ }^{12}$, possui um vínculo histórico com o campo evangélico. Tal como seu marido deputado, alegava pertencimento religioso à Igreja Batista. Antes de se eleger vereadora, Sônia afirma que desenvolvia um trabalho "junto às comunidades evangélicas, não só batistas mas todas, absolutamente todas", que consistia, principalmente, em palestras para casais, mulheres e jovens. Por certo este fato contribuiu para conquistar votos para a sua eleição, embora garanta que seu ingresso na política não tenha partido da igreja.

Portanto, da mesma forma como no meio afro-brasileiro portoalegrense, e não só nele, predomina o vínculo de Collares com as religiões afro-brasileiras, no meio evangélico porto-alegrense, e mesmo para alem dele, é também sabida a relação de Sônia Santos com o campo evangélico.

Porém, e de forma semelhante à coligação anterior, em seus discursos e pronunciamentos televisivos de campanha, ambos os políticos não apelaram nem acionaram diretamente a sua condição religiosa. Utilizaram, porem, com alguma frequência, o termo "irmão", recorrente no campo religioso. Assim por exemplo: "nossos irmãos abandonados"; "tantos irmãos que sofrem", etc. Ou seja, assim como a coligação anterior, certamente os candidatos dessa coligação também jogavam e apostavam, durante a campanha eleitoral, com um não-dito que é "já sabido", não sem supor que a pertença religiosa pudesse lhes assegurar votos provenientes dos membros das mencionadas religiões, que, aliás, não deixaram de ser visitadas e procuradas pelos respectivos candidatos, ali, sim, tendo eles expresso sua identidade religiosa.

Mas, a não-veiculação explícita do seu pertencimento religioso talvez tivesse sido avaliada pelos coordenadores de campanha como a

\footnotetext{
${ }^{12}$ Sônia Santos foi vereadora pelo PTB, esposa do deputado evangélico (Igreja Batista) e médico Eliseu Santos, também do PTB. Assegura que seu ingresso na política ocorreu em razão da "lei das cotas" que obriga todos os partidos a indicar $25 \%$ de candidatas mulheres.
} 
melhor estratégia eleitoral uma vez que se publicizassem a sua identidade religiosa poderiam, de um lado, carrear votos de membros dessas religiões mas que seriam, seguramente, insuficientes para garantir êxito eleitoral, alem de produzir como efeito perverso, indesejado, a rejeição das candidaturas de parte de pessoas pertencentes a outros credos.

A questão que fica em aberto, por isso mesmo, é saber até que ponto o vínculo religioso de ambos os candidatos constituiu-se num apelo eleitoral, ao lado de outros. Seja como for, a coligação representada por esta dupla obteve $20,07 \%$ dos votos válidos, classificando-se em segundo lugar e concorrendo ao segundo turno.

Enfim, é interessante constatar que esta coligação reuniu dois representantes de duas expressões religiosas não só diferentes mas, no Brasil, historicamente antagônicas entre si.

Aliás, a complexidade desta questão é ainda maior pois, como veremos, por ocasião da campanha para o segundo turno compareceram no vídeo, expressando seu apoio ao candidato da Frente Popular, dois importantes líderes de facções religiosas antagônicas e diretamente implicadas numa espécie de "guerra santa"13 : o "Bispo Rodrigues", deputado federal e principal articulador político da Universal, e Adalberto Pernambuco Nogueira, presidente do CEUCAB, do Rio Grande do Sul. Isto significa que por ocasião das eleições, em Porto Alegre, ocorreu, ao menos por um momento, um esfriamento e silenciamento da "guerra espiritual" referida.

A terceira coligação à prefeitura de Porto Alegre que se aproximou do campo religioso por ocasião da campanha eleitoral para o executivo municipal foi, como já disse, a Frente Popular, vitoriosa no segundo turno. Foi, justamente, no programa eleitoral gratuito do segundo turno que isto ocorreu de forma explícita.

Com efeito, nos dias 18 e 19 de outubro o pastor Hermílio Lima (Vice-Presidente da Assembléia de Deus Madureira - RS), compareceu no programa do PT declarando seu voto para o candidato da Frente Popular Tarso Genro. Disse ele, textualmente:

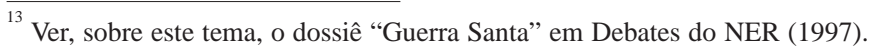


"Nós como evangélicos, há doze anos atrás vimos uma experiência transformadora e renovadora na cidade de Porto Alegre e estaremos mais uma vez apoiando o senhor Tarso Genro, juntamente com a Frente Popular, para governar esta cidade”.

Nos dois dias seguintes, 20 e 21, portanto oito dias antes da eleição, cinco outros líderes de diferentes religiões e igrejas compareceram nos programas para efetuarem um pronunciamento em favor da candidatura de Tarso Genro a prefeito municipal. Trata-se de líderes religiosos de prestígio que fizeram uso de sua autoridade e legitimidade para contribuir para a eleição do candidato do PT, seja declarando publicamente seu voto seja convocando os membros das suas religiões e igrejas a fazerem o mesmo. Foram, pela ordem, um Irmão Marista católico, um reverendo da Igreja Anglicana do Brasil, um Bispo da Igreja Universal, um Pastor de uma Igreja Batista e um Presidente de federação umbandista.

O primeiro a se pronunciar foi o representante da igreja católica. Irmão Antônio Cecchin é conhecido em Porto Alegre pelos seus longos anos de atuação junto às camadas de baixa renda da periferia da cidade. Sua fala teve o seguinte teor:

"Tarso Genro já demonstrou que tem uma prática política muito próxima do Evangelho de Jesus de Nazaré. É por isso que nós religiosos e pessoas de boa vontade vamos votar em Tarso Genro com muita alegria e grande satisfação no dia 29 de outubro".

O reverendo Maurício de Andrade, da Igreja Anglicana do Brasil, apareceu no vídeo com a indumentária religiosa e assim se pronunciou:

"Como religioso e clérigo da Igreja Episcopal Anglicana do Brasil eu vou votar em Tarso porque acredito que Tarso é quem representa e manterá as mudanças e transformações que estão acontecendo na cidade de Porto Alegre”.

Bispo Rodrigues, da Igreja Universal, deputado federal eleito em 1998 pelo Rio de Janeiro e "um dos 10 homens fortes da Universal” (Zero Hora, 12/11/2000, p. 14), apareceu no programa eleitoral da Frente Popular, 
ao lado de Paulo Gouvea, pastor da IURD e deputado federal pelo Rio Grande Sul eleito nas eleições de 1998. Este só emprestou a sua imagem pois coube ao bispo Rodrigues efetuar o seguinte depoimento:

"Por causa dos seus projetos sociais e também da sua ética em governar, você evangélico vote em quem governa com ética. Vote no Partido dos Trabalhadores. Vote em Tarso Genro”.

O quarto depoimento de religiosos em favor da candidatura Tarso Genro proveio do Pastor Paulo Lima, da Igreja Batista Nova Vida. Disse ele: "Estamos recomendando a candidatura de Tarso Genro pelo seu comprometimento com o projeto Vida Nova, projeto este da Igreja Batista Nova Vida que vai atender os menos favorecidos aqui da Restinga Nova" ${ }^{14}$.

Enfim, o último religioso a tomar a palavra em favor do candidato da Frente Popular foi Adalberto Pernambuco Nogueira, presidente do Conselho Superior dos Cultos Afro-Brasileiros (CEUCAB), o qual assim se pronunciou:

"Porque Tarso Genro? Porque como prefeito foi quem nos deu a abertura às religiões chamadas religiões dos oprimidos. Por isso, o nosso apelo para que todos os religiosos dêem o seu voto em Tarso Genro".

Como se pode ver, os cinco religiosos representam importantes expressões religiosas existentes na cidade, assim como no Estado e no Brasil: a católica, a evangélica e a mediúnica. Nota-se que os dois primeiros depoimentos restringem-se a tornar pública a declaração de voto dos seus anunciantes (Irmão Antônio Cecchin e Reverendo Maurício de Andrade), subentendendo que quem reconhece sua legitimidade fará o mesmo. Já os três últimos, Bispo Rodrigues, pastor Paulo Lima e o umbandista A. Pernambuco, são mais incisivos no sentido de pedir aos evangélicos (os dois primeiros) e aos "religiosos" - entenda-se os membros das religiões afro-brasileiras - (o último), para votarem em Tarso Genro.

\footnotetext{
${ }^{14}$ O Bairro Restinga está localizado na zona sul de Porto Alegre e possui uma população estimada de 60.000 habitantes.
} 
Todos apresentam uma justificativa do seu apoio ao candidato do PT. "Por ter uma prática política muito próxima do Evangelho" (Irmão Antônio Cecchin); " porque representa e manterá as mudanças que transformações que estão acontecendona cidade de PortoAlegre" (Reverendo Maurício de Andrade); "pelo seu comprometimento com o projeto Vida Nova" (Pastor Paulo Lima); "porque como prefeito foi quem nos deu a abertura às religiões dos oprimidos" (Adalberto Pernambuco Nogueira); "porcausa dos seus projetos sociais e também da sua ética em governar” (Bispo Rodrigues) $)^{15}$.

\section{II - Política e Religião na campanha para o legislativo municipal}

Já mencionei acima que foi por ocasião da campanha televisiva veiculada no espaço da propaganda eleitoral gratuita para a Câmara Municipal de Porto Alegre que a relação entre religião e política se fez mais direta em razão, sobretudo, de alguns candidatos que expressaram claramente o seu pertencimento religioso, acompanhado de um discurso religioso, e de outros que embora não se declarassem agentes religiosos também fizeram uso de um apelo religioso. No seu conjunto somam 17 candidatos e vamos agora discorrer, ainda que sucintamente, sobre cada um deles.

\section{Os candidatos religiosos}

Para uma melhor clareza na exposição optei pela classificação religiosa dos candidatos - dividindo-os em evangélicos, católicos e afro-brasileiros - ao invés de uma apresentação dos mesmos a partir de sua inserção político-partidária.

No termo evangélicos incluo os candidatos pertencentes a igrejas neopentecostais (como a Universal do Reino de Deus), pentecostais (como a Igreja Assembléia de Deus e Igreja do Evangelho Quadrangular) e protestantes históricas (como a Igreja Batista e, mesmo, a Igreja Adventista do Sétimo Dia) ${ }^{16}$.

\footnotetext{
${ }^{15}$ As relações da Igreja Universal com o Partido dos Trabalhadores será objeto de análise mais à frente.

${ }^{16}$ Há diferentes classificações do campo evangélico no Brasil em razão, sobretudo, de alguns pontos controvertidos como, por exemplo, a noção de neo-pentecostalismo, ou pentecostalismo autônomo, e a inclusão, ou não, de igrejas como Adventista e Testemunhas de Jeová no âmbito do protestantismo (Sobre esta questão ver Corten, 1996; Oro, 1996; Antoniazzi et al. 1994; Fernandes et al. 1998; Mariano 1999).
} 
O quadro a seguir apresenta alguns dados informativos sobre os candidatos evangélicos.

\section{Quadro I - Evangélicos}

\begin{tabular}{|c|c|c|c|c|c|}
\hline Denominação & Nome & Função & Partido & Votos & Situação \\
\hline Universal & Valdir Caetano da Silva & Pastor & PTB & 10.913 & Eleito \\
\hline Universal & Almerindo da Rosa Filho & Pastor & PFL & 7.645 & Eleito \\
\hline Universal & Veranice Neto & Membro & PPB & 186 & Não-eleita \\
\hline \multicolumn{2}{|l|}{ Total votos Universal } & \multicolumn{4}{|c|}{18.744} \\
\hline Assembléia de Deus & Eliseu Sabino & Pastor & PTB & 3.665 & Não-eleito \\
\hline Assembléia de Deus & Willis Taranger & Membro & PTB & 2.491 & Não-eleito \\
\hline Assembléia de Deus & Paulo Eliseu & Evangelis & PSDB & 1.714 & Não-eleito \\
\hline Assembléia de Deus & Flavio Batista & Membro & PTB & 982 & Não-eleito \\
\hline \multicolumn{2}{|l|}{ Total votos Ass. Deus } & \multicolumn{4}{|c|}{8.842} \\
\hline Quadrangular & Nilo Sergio S. dos Santos & Pastor & PTB & 2.333 & Não-eleito \\
\hline \multicolumn{2}{|c|}{ Total votos Quadrangular } & \multicolumn{3}{|c|}{2.333} & \\
\hline \multirow{2}{*}{$\begin{array}{l}\text { Batista Filadélfia } \\
\text { Total votos Bat. Fil. }\end{array}$} & \multirow[t]{2}{*}{ Claudio Conceição } & \multirow[t]{2}{*}{ Membro } & \multirow[t]{2}{*}{$\mathrm{PL}$} & 1.949 & \multirow[t]{2}{*}{ Não-eleito } \\
\hline & & & & 1.949 & \\
\hline Adventista & João Caetano & Membro & PSC & 344 & Não-eleito \\
\hline Total votos Adventista & & & & 344 & \\
\hline \multicolumn{2}{|c|}{ TOTAL DE VOTOS EVANGÉLICOS } & \multicolumn{4}{|c|}{32.212} \\
\hline
\end{tabular}

O próximo quadro refere-se aos candidatos católicos.

\section{Quadro II - Católicos}

\begin{tabular}{lllll} 
Nome & Função & Partido & Votos & Situação \\
\hline João Carlos Nedel & Leigo & PPB & 6.039 & Eleito \\
Claudiomir & Padre & PDT & 1.864 & Não-eleito \\
\hline
\end{tabular}

TOTAL

7.903 
$\mathrm{O}$ quadro a seguir contempla os candidatos pertencentes às religiões afro-brasileiras.

\section{Quadro III - Religiões Afro-Brasileiras}

\begin{tabular}{lllrl} 
Nome & Função & Partido & Votos & Situação \\
\hline Jorge Verardi & Pai-de-Santo & PDT & 1.994 & Não-eleito \\
Beto do Nagô & Pai-de-Santo & PMDB & 1.109 & Não-eleito \\
Aureo Rodrigues & Pai-de-Santo & PDT & 451 & Não-eleito \\
Danilo Andrade & Pai-de-Santo & PFL & 421 & Não-eleito \\
Luiz C. Melo & Presidente de terreiro & PPS & 1.668 & Não-eleito \\
Total & & & 5.643 & \\
\hline
\end{tabular}

TOTAL DE VOTOS - CANDIDATOS RELIGIOSOS $\quad 45.758$

Como se pode ver no quadro I, a Universal fez, sozinha, mais votos do que todas as outras igrejas evangélicas juntas que apresentaram candidatos ao legislativo municipal de Porto Alegre. Levando-se em conta que na capital gaúcha um candidato necessita de cerca de 6.000 votos para se eleger, infere-se que - embora, é claro, há sempre que se considerar a situação de cada legenda - a Universal, que recolheu quase 19.000 votos, poderia, eventualmente, ter eleito 3 vereadores, ao invés de 2. Admitindose, também, que tivesse havido uma aliança evangélica que transcendesse as denominações, poderia-se supor que este segmento religioso teria tido capital político suficiente para eleger até 5 vereadores, posto que, no seu conjunto, seus candidatos obtiveram mais de 30.000 votos.

Contrariamente à potencialidade política evangélica, nota-se, no quadro III, que os 5 agentes afro-brasileiros não receberam juntos, votação suficiente para eleger um único candidato ${ }^{17}$. Já o quadro II retrata a votação de 2 candidatos católicos, um leigo e outro sacerdote, que, durante a campanha eleitoral televisiva se identificaram como tal. No entanto, segundo um levantamento realizado pelo próprio candidato leigo, João

${ }^{17}$ As razões do fracasso de umas e do sucesso de outras religiões serão analisadas mais à frente. 
Carlos Nedel, houveram 11 candidatos católicos para a Câmara Municipal de Porto Alegre e juntos totalizaram 34.865 votos. Entre os 11, 4 se elegeram, a saber: o próprio Nedel, do PPB, eleito com 6.039 votos, Beto Moesch, do PPB, com 6.295 votos, Ervino Besson, do PDT, com 4.179 votos, e Carlos Alberto Garcia, do PSB, com 5.580 votos.

Nota-se, ainda, no quadro I, que os candidatos da IURD foram eleitos por partidos tidos como de direita, PFL e PTB, embora, como vimos, por ocasião da campanha no segundo turno para o executivo municipal a IURD tenha apoiado o candidato de esquerda, Tarso Genro. Adianto, porem, que cinco meses após a posse na Câmara Municipal, ambos os pastores mudaram de sigla partidária, ingressando no PL, e passaram a apoiar o prefeito do PT Tarso Genro. Aliás, a mesma mudança de sigla partidária em direção ao PL, com o consequente apoio à prefeita do PT Stela Farias, ocorreu recentemente em Alvorada, município da Grande Porto Alegre (Zero Hora, 1/5/2001). Diga-se de passagem que assim procedendo os evangélicos em questão estão reproduzindo uma prática recorrente na política brasileira, em distintos níveis, qual seja, a da migração partidária.

Outro aspecto que sobressai nos quadros acima é que não houve nenhuma candidatura de algum religioso nos partidos que formaram a Frente Popular, liderada pelo PT. Os partidos preferidos foram, pela ordem: PTB (5 candidatos), PDT (3 candidatos), PSDB (2 candidatos), PFL (2 candidatos), PMDB (1 candidato), PL (1 candidato), PSC (1 candidato), PPS (1 candidato) e PSC (1 candidato).

A não presença de candidatos religiosos nos partidos de esquerda poderia dar a entender que os mesmos estariam substancialmente inclinados a opções e tendências conservadoras. Sugiro, ao contrário, hipoteticamente, que tal ausência nos partidos de esquerda, deve-se, nos dias atuais, menos à resistência das religiões àqueles partidos, sobretudo ao PT, e mais à resistência dos próprios partidos em questão em relação às igrejas e às religiões. Ou seja, igrejas como a Universal estão mudando sua concepção e consequente relação com os partidos de esquerda mas estes não parecem ainda ter mudado suas representações sobre a religião e as igrejas, mormente pentecostais. Ademais, sugiro, como escrevi em 
outro lugar, relativamente aos pentecostais, que "os conservadores encontram mais rapidamente as chaves da subjetividade política que o pentecostalismo promove", e que seriam as formas de relação entre os atores políticos estabelecidos e os pentecostais que determinam "a direção mais ou menos conservadora que adquirem alguns dos seus itens políticos" (Oro \& Seman, 1997:143). Paul Freston já havia mostrado, por exemplo, que por ocasião da Constituinte de 1988 o comportamento da bancada evangélica não estava mais à direita do que média da Assembléia Nacional Constituinte e que seu apoio ao então candidato a presidente F. Collor de Melo não era inexorável. Segundo aquele autor, a esquerda poderia ter revertido a situação ou ainda ganhar os votos evangélicos. O que estava em jogo não era a unívoca disposição conservadora dos evangélicos mas um êxito conservador na interpelação de sua sensibilidade política (Freston, 1993). Por sua vez, A. Corten também sublinha, a partir de suas pesquisas sobre o pentecostalismo brasileiro e latino-americano, que, embora haja uma diversidade de pentecostalismos segundo os países, de uma forma geral eles não se situam mais à direita do que a média da população (Corten, 1997:27).

Estes estudos nos propõem algumas pistas no sentido de encaminhar explicações diversificadas e não unívocas na percepção não só de uma tendência politicamente conservadora dos líderes religiosos mas também de uma diversidade de comportamentos e tendências políticas, cujas expressões que sobressaem resultam mais de situações históricas particulares e de encontros de sensibilidades e subjetividades do que de essencialismos petrificados e imutáveis.

\section{Análise do discurso dos candidatos religiosos}

A análise do discurso dos candidatos religiosos, tal como foi veiculado no horário de propaganda eleitoral gratuita na televisão, irá privilegiar quatro unidades temáticas que, a meu ver, comporiam a estrutura básica da organização dos seus discursos. São elas: 
a) a apresentação dos candidatos, ou seja, a auto-apresentação discursiva e a forma como veiculou a sua imagem no vídeo;

b) o histórico dos candidatos, isto é, a explicitação de trajetórias pessoais e realizações efetuadas, dentro ou fora do campo político, que lhes assegura um capital político;

c) os objetivos dos candidatos, isto é, as propostas, projetos e fins que perseguem e se propõem a alcançar em caso de eleição;

d) a afinidade religiosa dos candidatos, ou seja, sua expressão de vínculo ou relação com um grupo religioso específico.

Antes, porém, de passarmos à análise veremos um quadro demonstrativo do número de vezes que cada candidato compareceu no vídeo.

\section{Quadro IV - Comparecimento no vídeo dos candidatos religiosos}

\begin{tabular}{lllll} 
Denominação & Nome & Função & Partido & Vezes \\
\hline Universal & Valdir Caetano & Pastor & PTB & 2 \\
Universal & Almerindo & Pastor & PFL & 4 \\
Universal & Veranice Neto & Membro & PPB & 4 \\
\hline & & & & \\
A. Deus & Eliseu Sabino & Pastor & PTB & 2 \\
A. Deus & Willis Taranger & Membro & PTB & 2 \\
A. Deus & Paulo Eliseu & Evangelista & PSDB & 7 \\
A. Deus & Flavio Batista & Membro & PTB & 2 \\
\hline
\end{tabular}

$\begin{array}{lllll}\text { Quadrangular } & \text { Nilo S. dos Santos } & \text { Pastor } & \text { PTB } & 2\end{array}$

Batista Filadelfia $\quad$ Claudio Conceição Membro $\quad$ PL 3

\begin{tabular}{lllll} 
Ad. Sétimo Dia & João Caetano & Membro & PSC & 4 \\
\hline TOTAL & & &
\end{tabular}




\begin{tabular}{lllll} 
Denominação & Nome & Função & Partido & Vezes \\
\hline Católicos & João C. Nedel & Leigo & PPB & 4 \\
& Claudiomir & Padre & PDT & 2 \\
\hline TOTAL & & & $\mathbf{6}$
\end{tabular}

\begin{tabular}{lllll} 
Denominação & Nome & Função & Partido & Vezes \\
\hline Afro-brasileiros & Jorge Verardi & Pai-de-Santo & PDT & 1 \\
& Beto do Nagô & Pai-de-Santo & PMDB & 3 \\
& Aureo Rodrigues & Pai-de-Santo & PDT & 2 \\
& Danilo Andrade & Pai-de-Santo & PFL & 3 \\
& Luiz C. Melo & Pres. de terreiro & PPS & 4
\end{tabular}

A principal observação que se pode tirar desta tabela é que, malgrado alguma incorreção numérica que porventura contenha, não há uma relação direta entre o número de vezes de comparecimento no vídeo e o sucesso eleitoral. O campeão de vezes de exposição no vídeo, Paulo Eliseu, da Assembléia de Deus, não foi eleito. Também não foram eleitos os candidatos João Caetano, Luiz C. Melo, Veranice Neto, que tiveram 4 comparecimentos cada um. Os eleitos compareceram 4 vezes (Almerindo e João Nedel) e 2 vezes (o mais votado entre todos os religiosos: Valdir Caetano, da Universal $)^{18}$.

A média de tempo de cada aparecimento no vídeo foi de 13 segundos, alguns reduzindo-se a 11 e outros a 15 segundos.

Passemos agora à análise de conteúdo dos discursos dos candidatos religiosos, iniciando pelos evangélicos e, dentre eles, os três da Universal.

\footnotetext{
${ }^{18}$ Suponho que a variação de comparecimento no vídeo segundo os candidatos obedece a um cálculo que contempla a relação existente em cada coligação/partido entre o tempo disponível para sua propaganda eleitoral televisiva e o número de candidatos registrados na mesma coligação/partido.
} 


\subsection{Universal do Reino de Deus}

Valdir Caetano da Silva, o terceiro vereador mais votado entre todos quantos concorreram à Câmara Municipal de Porto Alegre, é paulistano e chegou a Porto Alegre há três anos e meio. Neste cidade era apresentador do programa radiofônico Nosso Tempo que a Universal detém nas manhãs de segunda a sexta-feira na Radio Capital. É pastor há um ano e quando concorreu à vereança estava filiado ao PTB há um ano e meio (Jornal Zero Hora, 12/11/2000).

Sua propaganda televisiva consistiu em duas aparições bem distintas. A primeira foi na forma de um clip, de 15 segundos que iniciava com uma carreata de cerca de 20 carros passando em frente a três centenas de pessoas aglomeradas em ambos os lados de uma rua, todas portando bandeiras brancas com os dizeres: "PTB" e a frase: "É para mudar; vereador Valdir Caetano”. Este se encontrava sobre um pequeno carro aberto, sorrindo e acenando para os populares. Vestia uma camiseta branca que ostentava sua própria foto estampada no peito. Enquanto a carreata trafegava por este cenário ouvia-se a seguinte frase:

"Porto Alegre reconhecida e vitoriosa levará Valdir Caetano, 14777, para a Câmara de Vereadores. Valdir Caetano, PTB, trabalho pela nossa cidadania”.

A propaganda finalizava com a lente focando o rosto do candidato que sorrindo fazia sinal positivo com o polegar direito.

Em sua segunda aparição no vídeo, Valdir Caetano vestia paletó escuro, camisa branca e gravata amarela. Mostrava-se no vídeo somente a parte superior do corpo, e ele fazia o seguinte pronunciamento:

"Amigos! Tenho trabalhado na obra social de afirmação de valores da cidadania e família. Na Câmara de Vereadores, com teu voto, continuarei com o mesmo empenho pois entendo que a política tem que ser ética e também solidária. Valdir Caetano, 14777”. 
Almerindo da Rosa Filho compareceu no vídeo vestindo terno e gravata marrom, a lente focando também somente a parte superior do corpo. Via-se embaixo da tela as palavras: "pastor Almerindo - PFL" e no canto superior da mesma a imagem estática do catavento, em verde e amarelo, símbolo de G. Bonow, candidato a prefeito do partido. Almerindo efetuou, em suas aparições no vídeo, dois pronunciamentos, bastante semelhantes. Disse ele:

"Eu sou o pastor Almerindo. Meu numero é 25632. Vou lutar pelo povo evangélico e por uma Porto Alegre melhor. Fé para mudar. Vote em Almerindo. Vote em Bonow. Pastor Almerindo, 25632";

"Sou o pastor Almerindo, 25632, na luta pelo evangelho, pela educação, pelo trabalho e pela saúde. Fé para mudar, 25632. Porto Alegre, conto com teu voto. Pastor Almerindo, 25632”.

Veranice Neto apareceu no vídeo vestindo camisa branca abotoada até o pescoço e uma blusa preta aberta no peito. Lábios suavemente pintados e brincos discretos. Sua imagem foi projetada sobre um cenário de fundo em movimento que constava de uma rua popular com casas, carros, pessoas e cães.

Seu pronunciamento foi o mesmo ao longo de toda a campanha. Disse ela:

"Sou evangélica, membro da Igreja Universal do Reino de Deus. Atuarei nos direitos cristãos, saúde, educação e também contra a violência. Veranice Neto, 11117”.

Procedo agora à analise de conteúdo das mensagens desses três candidatos, a partir da categorização acima proposta.

Quanto à unidade temática apresentação, notamos que os dois pastores tendem a passar no vídeo o que entendem ser a imagem de seriedade (paletós e gravatas) e um deles a imagem de certa modernidade (gravata amarela). $\mathrm{O}$ mesmo aspecto de seriedade, associada a alguma dose de puritanismo, aparece na vestimenta da candidata a vereança. Alem disso, todos declinam os seus nomes e números eleitorais. No 
entanto, chama a atenção na propaganda televisiva de Valdir Caetano a sua não identificação evangélica e, muito menos, com a Universal. Precisa-se ter um olhar muito apurado para perceber entre os populares que aparecem na montagem televisiva de uma de suas propagandas, que alguns deles ostentam em suas camisetas ou bandeiras uma pomba, símbolo da Universal.

Já o segundo pastor da Universal procedeu completamente diferente do primeiro. Enquanto aquele não revelou a sua identidade religiosa este identifica-se como pastor; mas tal como o anterior, não expressa o seu vínculo institucional com a Igreja Universal do Reino de Deus.

Por seu turno, Veranice Neto é a única candidata da Universal a declarar o seu pertencimento confessional. No entanto, há aqui um importante esclarecimento a ser feito.

Os dois pastores acima mencionados foram lançados como candidatos "oficiais" da Universal. Receberam, consequentemente, todo o apoio da mesma, cujo resultado, como sabemos, foi a eleição de ambos. Já Veranice se lançou como candidata por iniciativa própria, ou de membros do seu partido, não tendo recebido nenhum apoio da Igreja. No entanto, mesmo sabendo que não contava com apoio da IURD, fez uso explícito do seu vínculo a esta Igreja na esperança de que este fato pudesse atrair votos. O que não ocorreu, levando-se em conta a sua reduzida votação (186 votos).

O ítem história, ou atividades realizadas, não é contemplado pelos candidatos da Universal. Ocorre que os três estão debutando na política. Somente o candidato Valdir Caetano afirma, genericamente: "tenho trabalhado na obra social de afirmação de valores da cidadania e família”. Esta é uma frase cujo significado é compreendido somente para quem conhece o candidato ${ }^{19}$.

Seja como for, o conteúdo do discurso de Valdir Caetano sugere algo que retomaremos mais à frente, qual seja, o trabalho assistencialista

\footnotetext{
${ }^{19}$ O jornal Zero Hora veiculou que Valdir Caetano, nos últimos três anos, "com a ajuda do programa Nosso Tempo, que comanda das $7 \mathrm{~h}$ às $9 \mathrm{~h}$ na Rádio Capital, distribuiu 38 mil ranchos, 17 mil pares de sapatos, 3.040 oportunidades de empregos, 933 atendimentos jurídicos e 4,2 mil cortes de cabelo" (Zero Hora, 12/11/2000, p. 14).
} 
de algumas igrejas enquanto componente estratégico não só de proselitismo mas também de inserção no espaço público e na política.

Já a categoria proposta é contemplada pelos três candidatos. $\mathrm{O}$ primeiro, após anunciar que tem trabalhado na "obra social de afirmação de valores da cidadania e família", acrescenta que "Na Câmara de Vereadores (...) continuarei com o mesmo empenho...", dando a entender que dará continuidade ao trabalho social que vem desenvolvendo. Por seu turno, o segundo pastor propõe-se a "lutar pelo povo evangélico e por uma Porto Alegre melhor; pela educação, pelo trabalho e pela saúde". Enfim, o objetivo da candidata é atuar "nos direitos cristãos, saúde, educação e também contra a violência”.

Como se vê, as propostas dos candidatos da Universal não diferem, fundamentalmente, das propostas dos políticos em geral. Alguma especificidade religiosa pode ser encontrada, no entanto, em expressões como: "Fé para mudar" (Pastor Almerindo); "Atuarei nos direitos cristãos" (Veranice Neto); "entendo que a política tem que ser ética e também solidária” (Valdir Caetano).

A categoria afinidade, já foi adiantado acima, revela um quadro em que a candidata expressa seu vínculo denominacional (Universal) e religiosa (evangélica), enquanto que o pastor Almerindo afirma somente a sua afinidade evangélica, mas não denominacional, e Valdir Caetano não manifesta nenhuma afinidade específica, a tal ponto de que quem não soubesse a sua condição de pastor da Universal durante a campanha televisiva dificilmente iria suspeitar desta sua afinidade religiosa.

Sugiro que estamos aqui diante de um procedimento estratégico da IURD em relação à campanha televisiva dos seus candidatos, ou seja, em relação ao grande público, pois, enquanto um não revela a sua identidade religiosa outro afirma publicamente não somente a sua condição evangélica mas também de pastor. No entanto, nenhum deles revelou a sua vinculação com a Universal. Talvez assim procederam os coordenadores políticos da Igreja para não despertarem a atenção seja de pesquisadores, da imprensa, esta última tendo, nos últimos anos, produzido várias matérias (jornalísticas e televisivas) tidas como negativas por parte da Universal, ou do público em geral, onde é alto o índice de 
rejeição desta Igreja. Consequentemente, houve a opção pela não revelação para fora da própria igreja da identidade religiosa de Valdir Caetano (que obteve, mesmo assim, o maior volume de votos), e pela veiculação somente da condição de pastor evangélico, de parte de Almerindo, supondo, dessa forma, poder este candidato alcançar votos de fieis eleitores deste amplo segmento religioso.

\subsection{Assembléia de Deus}

A Igreja Assembléia de Deus possuía quatro candidatos a vereador em Porto Alegre: um pastor, dois evangelistas e um membro da igreja. Todos apresentaram-se espontaneamente e a cúpula dirigente da igreja local apoiou oficialmente dois candidatos, o já vereador e pastor Eliseu Sabino e o membro Willis Taranger. Embora estes tenham recebido mais votos do que os outros, não foi o suficiente para se elegerem, posto que houve uma pulverização de votos entre os quatro candidatos da Igreja. Assim sendo, nem o então vereador representante da Assembléia, Eliseu Sabino, alcançou a votação suficiente para se eleger.

Eliseu Sabino é "assembleiano" desde criança, pastor e vereador eleito em $1996^{20}$. Durante a última campanha eleitoral apareceu no vídeo vestindo terno cinza e gravata bordô. Este foi o seu pronunciamento:

"Certo de que cumpri a missão que por você me foi confiada, peço mais uma vez o seu voto para continuar a nossa luta. Está dito nas Escrituras: 'quando um justo governa o povo se alegra'. Vote certo, vote Eliseu Sabino, 14660”.

Willis Taranger é filho do pastor sueco Nils Taranger que chegou, juntamente com sua esposa Mary, a Porto Alegre em novembro de 1946

\footnotetext{
${ }^{20}$ É pastor, com curso de teologia em São Paulo, advogado e presidente da juventude da igreja Assembléia de Deus. Concorreu a vereador em 1992, pelo PDT, obtendo 2.098 votos, insuficiente para ser eleito. Concorreu novamente em 1996, pelo PTB, e se elegeu, com 3.968 votos, tendo sido eleito como o primeiro vereador da Assembléia de Deus de Porto Alegre. Em 1998, tentou, sem êxito, uma vaga na Câmara Federal, ao concorrer para deputado, novamente pelo PTB, obtendo 7.980 votos, dos quais 4.428 obtidos em Porto Alegre.
} 
e assumiu a chefia da igreja Assembléia de Deus no Estado em 1955, em substituição a outro casal sueco, fundadores da igreja no Rio Grande do Sul Elisabeth e Gustavo Nordlund. Willis não detém outro cargo na Assembléia de Deus a não ser o de administrador do Lar Esperança mantido pela mesma igreja ${ }^{21}$. Assim se pronunciou durante a campanha eleitoral televisiva:

"Meu nome é Willis Taranger. Concorro à vereador porque acredito poder contribuir com a comunidade de Porto Alegre em projetos comunitários e sociais. Há 18 anos administro o Lar Esperança e um complexo de obras sociais. Meu número é 14880”.

Paulo Eliseu apareceu no vídeo de terno e gravata tendo como fundo uma foto da cidade de Porto Alegre. Repetiu o mesmo pronunciamento em suas 7 aparições no vídeo. Nelas, alem de afirmar a sua condição de evangelista da Assembléia de Deus, refere sua experiência no campo político enquanto assessor parlamentar. Disse ele:

"Evangelista da Assembléia de Deus, assessor parlamentar por vários anos, minha luta está baseada na fé, lealdade e trabalho - Paulo Eliseu, 45645”.

Enfim, Flávio Tavares é outro evangelista da Assembléia de Deus candidato a vereador. Apresentou-se também como membro do Conselho Tutelar - condição em que se encontram vários outros candidatos a vereadores, inclusive o acima candidato Eliseu Sabino, que nele atuou entre sua primeira candidatura (em 1992) e a segunda, em que foi eleito, em 1996 - o que pode ser entendido como sendo, para muitos, uma espécie de ante-sala da candidatura a um cargo político. Compareceu no vídeo vestindo paletó e gravata, e pronunciando o seguinte discurso:

"Meu irmão! Sou evangelista da Igreja Assembléia de Deus de Porto Alegre e membro do Conselheiro tutelar no segundo mandato. Moro no Bairro Cavalhada há 43 anos e conheço as

\footnotetext{
${ }^{21}$ Trata-se de uma entidade que se ocupa de crianças aidéticas.

Willis Taranger é formado em Engenharia Mecânica pela Universidade do Rio Grande do Sul.
} 
dificuldades das áreas da assistência pública, saúde e educação. Com seu apoio lutaremos com fé, muito trabalho e dedicação”.

A categoria apresentação é assim tratada pelos candidatos da Assembléia de Deus. Todos portam vestimentas condizente com sua concepção do que seja uma imagem de seriedade; declaram o seu nome e número eleitoral, menos o último candidato mencionado cujo nome e número aparecem somente por escrito abaixo da sua imagem. Dois revelam a sua condição de evangelistas da Assembléia de Deus e dois não o fazem. Casualmente são os dois candidatos não apoiados pela igreja que declinam o seu vínculo religioso para com a igreja, o mesmo tendo ocorrido, como vimos, em relação à candidata "independente" da Universal. Alem disso, um candidato apresenta-se como "assessor parlamentar" (Paulo Eliseu), outro como membro do Conselho Tutelar (Flávio Tavares), outro como administrador do "Lar Esperança e um complexo de obras sociais" (Willis Taranger). Por sua vez, Eliseu Sabino, não declara diretamente a sua condição presente de vereador. Contenta-se em dizer: "Certo de que cumpri a missão que por você me foi confiada". Ou seja, esta é uma afirmação que faz sentido para quem o conhece.

Quanto ao histórico de cada candidato, pode-se ver que Sabino, ao emitir a frase acima dá a entender ter efetuado realizações enquanto vereador. Não o diz, porem, diretamente e nem menciona quais são elas. Mesmo assim, permite-se afirmar ter "cumprido a missão" que lhe foi confiada. Paulo Eliseu, por sua vez, apresenta como elemento importante da sua história a sua condição de "assessor parlamentar por vários anos". Flavio, o conselheiro tutelar em segundo mandato e alguém que conhece os problemas do bairro onde mora. Willis Taranger informa que administra há 18 anos o Lar Esperança e um “complexo de obras sociais”.

Relativamente à unidade proposta, Sabino pede o voto para "continuar a nossa luta", sem dizer explicitamente qual é ela. Paulo Eliseu afirma que sua "luta está baseada na fé, lealdade e trabalho". Também não esclarece de que "luta" está falando. O objetivo de Flavio é lutar "com fé, muito trabalho e dedicação", contando, para tanto, com o apoio do eleitor. Enfim, W. Taranger expressa ser capaz de contribuir com a comunidade 
“em projetos comunitários e sociais”, sem porem especificá-los.

Como se pode ver, as propostas dos candidatos da Assembléia de Deus aparecem menos claras do que aquelas apresentas pelos candidatos da Universal.

Enfim, a afinidade religiosa é explicitada, como vimos, pelos dois candidatos não apoiados oficialmente pela Igreja. Ambos declaram o seu pertencimento à Assembléia de Deus enquanto evangelistas. $\mathrm{O}$ então vereador, como vimos, não declarou esta sua condição como também não revelou diretamente a sua condição de evangélico e, muito menos, de pastor assembleiano. Expressa diretamente a sua afinidade evangélica ao fazer uso, durante o seu programa, de uma frase bíblica que, da forma como é dita e vendo-se a sua sequência não deixa de ser uma forma indireta de auto-elogio do próprio candidato ${ }^{22}$. Por sua vez, W. Taranger também não esclarece o seu vínculo confessional, a não ser indiretamente, ao se referir que administra o Lar Esperança, sabidamente da Assembléia de Deus para quem pertence a este meio religioso.

\subsection{Evangelho Quadrangular}

A Igreja do Evangelho Quadrangular apresentou em Porto Alegre um único candidato a vereador, escolhido após a realização de prévias dentro da igreja para escolher seus candidatos ${ }^{23}$. O pastor Nilo Sérgio Santos dos Santos, 31 anos, vencedor da prévia para a capital, declarou ao Jornal Zero Hora que "as religiões estão começando a se conscientizar o espaço que perderam junto à sociedade nas últimas décadas por estar fechadas em si mesmas" (Zero Hora, 17/09/2000, p. 5).

\footnotetext{
${ }^{22}$ Recordo que a frase bíblica é: "quando um justo governa o povo se alegra”. Ao que segue, imediatamente: "Vote certo, vote Eliseu Sabino, 14660".

${ }^{23}$ Segundo o Jornal Zero Hora de 17 de setembro de 2000, a Igreja Quadrangular inovou neste ano de eleições pois, tal como um partido, efetuou prévias eleitorais entre os seus 10 mil fieis em Porto Alegre e $80 \mathrm{mil} \mathrm{no}$ interior do Estado. Definiu 59 candidatos oficiais no Estado a metade dos quais sendo composta de pastores. A tarefa foi coordenada por um pastor que definiu ser a meta da igreja concentrar os votos dos fieis e assim aumentar a presença da igreja na política (Zero Hora, 17/09/2000, Caderno Especial sobre Eleições 2000, p. 4).
} 
Compareceu no vídeo, durante a propaganda televisiva eleitoral, de paletó e gravata escura e camisa branca e com um largo sorriso nos lábios assim se pronunciou:

"Amigo não precisa de promessas. E como amigo de vocês quero continuar fazendo tudo aquilo que tenho feito. Eu me coloco à sua disposição para ser o seu representante na Câmara de Vereadores. Amigo vota assim. Nilo 14.120”.

A apresentação pessoal deste candidato segue o modelo dos demais evangélicos e da maioria dos candidatos em geral: usa terno e menciona seu nome e número eleitoral. Mas, trata-se de uma apresentação mínima pois não acrescenta mais nenhum outro dado. Não apresenta nenhum histórico pessoal, embora pretenda "continuar fazendo tudo aquilo que tenho feito". Como não menciona os "feitos", esta frase fica sem sentido, a não ser para quem o conhece. Igualmente, diz não fazer promessa, porque "amigo não precisa de promessas". No entanto, em seguida apresenta seu objetivo, também carente de sentido para o público em geral, de "continuar fazendo tudo aquilo que tenho feito". Enfim, não revela também nenhuma afinidade com nenhum segmento social ou religioso.

Nota-se, pois, que este candidato apresentou um discurso que pode fazer sentido somente para quem o conhece, ou seja, os membros da sua Igreja, considerando-se amigo (deles) e pondo-se a disposição (deles) para ser seu representante na Câmara de Vereadores.

\subsection{Igreja Batista Filadélfia}

O candidato da Igreja Batista Filadélfia, compareceu no vídeo de camisa azul, ao lado de uma moça que traduzia sua fala para a linguagem dos surdos-mudos. Disse ele:

"Deus é fiel. Sou Claudio Conceição, 20677. Morador do Parque dos Maias, Inspetor de Policia, evangélico, lidero os jovens da Igreja Batista Filadélfia. Presidente da Fectergs e trabalho junto às casas de recuperação evangélica. Lembre-se: 
um jovem livre das drogas é menos um assaltante nas ruas amanha. Povo de Deus, declare isto na hora de votar. Porto Alegre é do Senhor Jesus Cristo”.

Em sua apresentação este candidato procura mostrar-se jovem, com vestimenta informal. Refere seu nome, número, local de moradia e atividades e cargo que ocupa. Indiretamente refere também seu histórico pessoal, ao mencionar sua condição de policial, presidente da Fectergs, alem de líder da juventude da igreja. Sua proposta é apresentada de forma indireta, ou seja, ao referir que trabalha junto às casas de recuperação de drogados e solicitar ao povo de Deus que declare isto na hora de votar, ou seja, votando nele que está realizando este trabalho e continuará a se ocupar do tema. Sua afinidade religiosa é declarada ao se dizer evangélico e líder da juventude da Igreja Batista Filadélfia, alem de usar afirmações religiosas que via de regra somente os evangélicos o fazem, tais como: "Deus é fiel", "Povo de Deus", "Porto Alegre é do Senhor Jesus Cristo”.

\subsection{Igreja Adventista do Sétimo Dia}

Enfim, João Caetano, da Igreja Adventista do Sétimo Dia, apresentou o seguinte discurso:

"Meu irmão, seja inteligente, vote na gente. Eu não sou a solução. A solução é ter Cristo no coração. E com Cristo no coração juntos chegaremos à vitória. No dia primeiro de outubro para vereador vote João Caetano, 20777. Que Deus nos abençôe”.

Este candidato apresenta-se com vestimenta formal (terno e gravata) e com a Bíblia na mão esquerda, encostada à altura do coração. Revela seu nome e número eleitoral. Em suas duas últimas apresentações, ao lado da sua imagem no vídeo pode-se ler: " $O$ candidato da família Adventista”. Não apresenta nenhum indício de sua história passada nem de sua proposta enquanto vereador. Sua afinidade religiosa é 
revelada no uso das palavras Cristo (2 vezes) e Deus (1 vez), e pelas expressões: "A solução é ter Cristo no coração" e "Que Deus nos abençoe”, alem da frase constante no vídeo que dizia ser o representante da "Familia Adventista".

\subsection{Católicos}

João Carlos Nedel é um leigo, engajado em várias atividades da igreja católica, sendo, inclusive, ministro da eucaristia. Formado em Ciências Contábeis pela Pontifícia Universidade Católica do Rio Grande do Sul, concorreu, sem sucesso, à deputado estadual em 1994, obtendo 7.180 votos. Em 1996 concorreu a vereador, pelo PPB, tendo sido eleito com 5.107 votos. Nas eleições 2000 foi eleito com 6.039 votos. Estima que pelo menos $60 \%$ dos votos obtidos são provenientes do meio católico, das paróquias em que tem atuado. Afirma ter ingressado na política após ouvir, na Associação dos Dirigentes Cristãos de Empresa, uma palestra sobre "o compromisso político do Cristão". Decidiu, então, entrar na política "para evangelizar esta área, como uma missão", uma vez que tratase de um ambiente "que não estava sendo iluminado pelo evangelho".

Sua propaganda televisiva foi realizada diante da Câmara Municipal de Porto Alegre, onde, vestindo terno e gravata, efetuou a seguinte declaração:

"como vereador encaminhei 650 demandas de 78 bairros e 30 paróquias, apresentei 71 projetos de lei, entre eles o de criação do dia e do conselho municipal da família. Eu sou Nedel, cristão na palavra e na ação”.

Claudionir Ceron foi o único padre candidato a vereador em Porto Alegre. Segundo o jornal Zero Hora, possui 31 anos e coordena a Casa Aberta para crianças do Morro da Cruz, nos arredores da capital. Contava com o voto da juventude deste local e do Bairro Restinga Velha, votos, porém, que foram insuficientes para garantir a sua eleição. 
Compareceu no vídeo de camisa, ligeiramente aberta ao peito, cabelos longos, barba e bigode ralos. Seu pronunciamento foi o seguinte: "Na luta para que os pobres tenham melhores condições de vida a sociedade humana deve agir em cooperação. Por isso, minha ação será voltada ao resgate da vida, pela educação integral das crianças e adolescentes e em defesa dos direitos dos idosos. Padre Claudionir. Vereador, 12212. Para fazer mais, para fazer melhor".

A apresentação pessoal dos candidatos católicos parece ser mais objetiva do que a dos evangélicos em geral. O candidato leigo revela seu nome e sua condição atual de vereador. O padre, alem de auto-nominarse, deixa claro a sua condição sacerdotal. Alem disso, sua imagem, construída de forma intencional ou não, procura lembrar aquela de Cristo, reproduzida em santinhos e pinturas. Aliás, semelhante analogia, não desprovida de significado, entre a própria imagem televisiva e aquela tradicional do Cristo iconográfico, pôde ser vista no candidato Oliboni, do PT, que também, não por acaso, há anos representa o papel de Cristo na hoje tradicional procissão da Paixão de Cristo realizadas nas sextasfeiras santas na Vila Morro da Cruz, em Porto Alegre.

Quanto à história dos candidatos católicos, o primeiro apresenta números que dão conta de sua atividade como vereador: fica-se sabendo que atendeu "demandas" de bairros e paróquias e apresentou projetos de lei na Câmara. O segundo não explicita diretamente as suas atividades pregressas. No que concerne os objetivos, estes são apresentados de forma clara: educação integral das crianças e adolescentes e defesa dos direitos dos idosos. A última frase pronunciada é uma mera repetição de um slogan da campanha da coligação à qual o sacerdote pertencia. Já o candidato leigo não apresenta claramente seus objetivos para a próxima legislatura. Subentende-se a continuação das ações realizadas. Enfim, ambos os candidatos explicitam sua afinidade religiosa, com o cristianismo ("Eu sou Nedel, cristão na palavra e na ação") e com o catolicismo: "Padre Claudiomir". 


\subsection{Afro-Brasileiros}

Houve, como já mencionei, cinco candidatos ao legislativo municipal de Porto Alegre vinculados às religiões afro-brasileiras, sendo quatro pais-de-santo e um presidente de terreiro.

Jorge Verardi já havia concorrido a deputado estadual em 1990, tendo obtido 1.408 votos, dos quais 610 em Porto Alegre. Como na vez anterior, concorreu pelo PDT e nas eleições 2000 foi o único a comparecer no vídeo vestindo a indumentária religiosa. Efetuou a seguinte declaração:

"Sou Jorge Verardi do Xangô, babalorixá e presidente da Afrobras. Nas eleições de Porto Alegre nunca tivemos um representante. Por isso convoco os irmãos africanistas e umbandistas para fazer mais por Porto Alegre. Vote 12812. Com teu apoio e teu voto Porto Alegre terá mais Axé”.

Beto do Nagô, Roberto Fortes, compareceu no vídeo usando terno preto, camisa branca e gravata marfim. Segundo se poder ler em sua página na internet, é babalorixá desde os 16 anos, foi funcionário da Companhia Estadual de Energia e do Banrisul e tornou-se empresário do setor de segurança. Em sua primeira aparição declarou:

"Segurança e afro-umbandismo mais fortes. Afroumbandista lute pela nossa dignidade. No censo afirme nossa religião. No voto confirme 15789. Roberto Fortes é Beto do Nagô”.

Em seus dois outros programas no horário de propaganda eleitoral gratuita na televisão apareceu ao lado do deputado federal do PMDB Nelson Proença que o apresentou como candidato a vereador com estas palavras:

"Uma vida inteira dedicada à religião afro, à umbanda, às questões de segurança e à juventude. Roberto Fortes é Beto do Nagô", ao que seguiu imediatamente o candidato a vereador dizendo: "Na câmara continuarei a lutar pelas causas que sempre defendi. Você me conhece, conto contigo". 
Aureo Rodrigues compareceu no vídeo vestindo camisa branca, cor esta recorrente no meio religioso umbandista. Seu pronunciamento foi o seguinte:

"Cidadão de Porto Alegre!. Meu nome é Aureo Rodrigues. Tio Aureo. A nossa proposta é o trabalho que há 18 anos já desenvolvemos na cidade, nas vilas, nos bairros, junto aos religiosos, os motoristas de taxi, camelôs, idosos, pensionistas, e o nosso povo cansado das vilas que sofre a miséria e a fome do dia-a-dia. Conto com vocês em outubro e a confiança do teu voto. Para fazer mais, para fazer melhor. Chega de promessas. 12949, Aureo Rodrigues".

Danilo Andrade é outro pai-de-santo que já havia tentado, como Verardi, uma cadeira no legislativo estadual. Com efeito, em 1990 concorreu pelo PTB a deputado tendo obtido 506 votos, dos quais 346 em Porto Alegre. Durante vários anos animou um programa radiofônico semanal voltado para o público religioso afro-brasileiro. Compareceu nos programas televisivos vestindo camisa de cor branca, ao que acrescentou um colete de cor cinza. Em seus programas pronunciou, em dias diferentes, dois discursos semelhantes:

"Sou Danilo Andrade, Danilo de Oxalá. Radialista e babalorixá. Luto pela qualidade de vida e segurança da população. Meu número é 25252. Vote em Bonow e em Danilo Andrade. Este compromisso é nosso";

"Sou Danilo Andrade, Danilo de Oxalá. 25252. Radialista e babalorixá. Luto pela segurança, qualidade de vida e reconhecimento da religião afro-brasileira. Este compromisso é nosso. Para prefeito Bonow 25”.

Enfim, Luiz Carlos Melo é Ex-Delegado Regional do Trabalho, jornalista e presidente do Reino de Oxalá, prestigioso centro afroumbandista da cidade de Porto Alegre liderado pelo pai-de-santo Cleon de Oxalá. Em seu espaço no horário televisivo compareceu sempre com microfone na mão, atuando de forma semelhante a um repórter. Nesta 
condição, por exemplo, apareceu diante do prédio da Delegacia Regional do Trabalho afirmando:

“Aqui na Delegacia Regional do Trabalho nós criamos a central de atendimento ao trabalhador aidético de soropositivado. E criamos também uma central de atendimento psicológico aos trabalhadores desempregados. Na Câmara de Vereadores Municipal nós vamos fazer muito mais".

Em três outras oportunidades pôde-se ver Melo numa rua da cidade afirmando:

"Esta é a Avenida Presidente Roosevelt. Ela já teve o melhor comércio de Porto Alegre e o melhor carnaval. Hoje é a avenida do já teve. Alguém tem que falar pelo quarto distrito”.

A apresentação pessoal dos candidatos pertencentes ao campo religioso afro-brasileiro é relativamente divergente entre eles. Três paisde-santo (Verardi, Fortes e Andrade) explicitam claramente a sua condição de líderes religiosos. Somente o primeiro porem, apresenta-se vestindo indumentária religiosa. O quarto pai-de-santo (Rodrigues) prefere nomear-se como "Tio Aureo", e não "Pai Aureo", como é de praxe nesse meio religioso. Enfim, o presidente de terreiro não diz seu nome, nem numero eleitoral. Estes dados constavam somente por escrito abaixo da imagem do candidato. Verardi, alem disso, explicita a sua condição de presidente da federação de religiões afro-brasileiras chamada Afrobras. Danilo Andrade menciona a sua condição de radialista; Beto do Nagô esclarece que tem se ocupado com questões de segurança.

A categoria história é também parcialmente contemplada pelos candidatos afro-brasileiros. Alem dos dados constantes na apresentação pessoal, acima ditos, somente dois deles relatam suas atividades passadas. Aureo Rodrigues refere seu trabalho desenvolvido há 18 anos junto a certas categorias sociais e Melo esclarece que atuou na Delegacia Regional do Trabalho ao elencar duas de suas atividades.

O ítem proposta é o mais diluído e nebuloso de todos. Verardi, ao afirmar que "nunca tivemos (os afro-brasileiros) um representante" 
(na Câmara Municipal) está indiretamente propondo que sua ação nesta instituição será na defesa deste segmento religioso; Beto do Nagô, ao propor que irá “lutar pelas causas que sempre defendi”, está sugerindo que irá também se ocupar da defesa da religião afro-umbandista bem como em questões de segurança; a proposta de Aureo Rodrigues é continuar o trabalho que desenvolve há 18 anos junto a certos segmentos sociais; Danilo de Andrade também dá a entender que pretende continuar o trabalho que desenvolve visando a qualidade de vida e segurança da população e o reconhecimento da religião afro-brasileira; enfim, Melo afirma que na Câmara Municipal fará mais do que tem feito quando atuava, por exemplo, na Delegacia Regional do Trabalho. Propõe-se, também, a ser o porta-voz do "Quarto Distrito".

Enfim, a afinidade com as religiões afro-brasileiras é clara em três pais-de-santo: Verardi apresenta-se vestido como babalorixá e afirmase como tal; Danilo Andrade diz-se Danilo de Oxalá e veste camisa branca; já Aureo Rodrigues dilui o seu vínculo religioso afro-brasileiro ao dizer-se "Tio Aureo" e afirmar ter desenvolvido um trabalho junto a diversas categorias sociais e entre elas "os religiosos". Neste caso, ele está usando uma terminologia conhecida de quem pratica as religiões afro-brasileiras - que se consideram "religiosos", "de religião" - não para quem não domina os códigos linguísticos deste campo religioso. Enfim, Melo não apresenta nenhum indício de que mantém relação com as religiões afro-brasileiras.

O quadro ao lado apresenta uma síntese visual dos 17 candidatos religiosos mencionados e seu enquadramento nas quatro categorias que orientaram a análise.

\section{Quadro V - Situação dos candidatos religiosos em relação às quatro categorias de análise dos seus discursos}

\begin{tabular}{lllllll} 
Nome & Denominação Religiosa & Situação & Apresentaçãa & Histórico & Proposta & Afin. Rel. \\
\hline Valdir Caetano & Universal & Eleito & Sim & Em parte & Sim & Não \\
Almerindo & Universal & Eleito & Sim & Não & Sim & Em parte \\
Veranice Neto & Universal & Não-eleita & Sim & Não & Sim & Sim \\
Eliseu Sabino & A. Deus & Não-eleito & Sim & Em parte & Em parte & Em parte
\end{tabular}

Debates do NER, Porto Alegre, ano 2 n.3, setembro de 2001 


\begin{tabular}{|c|c|c|c|c|c|c|}
\hline Willis Taranger & A.Deus & Não-eleito & Sim & Sim & Sim & Em parte \\
\hline Paulo Eliseu & A. Deus & Não-eleito & Sim & Sim & Sim & Sim \\
\hline Flavio Batista & A. Deus & Não-eleito & Sim & Sim & Sim & Sim \\
\hline Nilo S. Santos dos Santos & Quadrangular & Não-eleito & Sim & Não & Não & Não \\
\hline Claudio Conceição & Batista Filadelfia & Não-eleito & Sim & Sim & Em parte & Sim \\
\hline João Caetano & Ad. Setimo Dia & Não-eleito & Sim & Não & Não & Sim \\
\hline João C. Nedel & Católica & Eleito & Sim & Sim & Em parte & Sim \\
\hline Claudiomir & Católica & Não-eleito & Sim & Em parte & Sim & Sim \\
\hline Jorge Verardi & Afro-brasileira & Não-eleito & Sim & Em parte & Em parte & Sim \\
\hline Beto do Nagô & Afro-brasileira & Não-eleito & Sim & Sim & Em parte & Sim \\
\hline Aureo Rodrigues & Afro-brasileira & Não-eleito & Em parte & Sim & Em parte & Em parte \\
\hline Danilo Andrade & Afro-brasileira & Não-eleito & Sim & Sim & Sim & sim \\
\hline Luiz C. Melo & Afro-brasileira & Não-eleito & Em parte & Sim & Sim & não \\
\hline
\end{tabular}

Como se pode ver, os discursos que contemplam as quatro categorias de análise dos discursos foram apresentados por dois candidatos da Assembléia de Deus, os evangelistas não apoiados oficialmente pela instituição, bem como por 1 pai-de-santo. Os candidatos que preencheram quase plenamente as quatro categorias foram outros pais-de-santo, bem como o candidato da Igreja Batista, os candidatos católicos e 1 candidato da Assembléia de Deus. Os candidatos que menos se enquadraram nas categorias estruturais do discurso de propaganda foram: o candidato da Igreja Quadrangular e o candidato da Igreja Adventista do Sétimo Dia. Os candidatos eleitos da Universal corresponderam medianamente às unidades temáticas discursivas selecionadas para análise. Por sua vez, o candidato católico eleito preencheu quase que integralmente as quatro categorias.

Esta análise nos permite concluir que ao menos no tocante aos candidatos religiosos aos cargos eletivos, não houve uma relação mecânica entre refinamento discursivo e êxito eleitoral. Em outras palavras, não garantiram para si um melhor resultado (eleição) os candidatos (religiosos) que apresentaram melhor performance discursiva, em detrimento dos que apresentam um discurso menos elaborado.

Resumindo o que precede podemos afirmar que assim como não houve uma relação direta entre o número de vezes de comparecimento dos candidatos no horário de propaganda eleitoral gratuita na televisão e sucesso eleitoral, também não houve uma relação entre 
performance discursiva (articulação da mensagem discursiva) e eficácia política. Houveram, pois, outras variáveis implicadas no êxito, ou fracasso, eleitoral dos candidatos religiosos. Passo, a seguir, a analisar uma delas, qual seja, a estrutura organizacional das instituições religiosas às quais os candidatos estão vinculados.

\section{A eficácia política do carisma institucional e do carisma pessoal}

Vimos que em Porto Alegre os dois candidatos da Universal, apoiados oficialmente pela igreja, lograram êxito eleitoral, enquanto que os demais candidatos de outras religiões não obtiveram o mesmo resultado, com exceção do já vereador e católico João Carlos Nedel. Sugiro que a explicação do êxito dos candidatos da Universal passa pela análise da organização estrutural desta igreja e do carisma institucional de que é detentora. Já o êxito do candidato católico deve-se ao seu carisma pessoal e sua relação destacada com a igreja católica, detentora histórica de carisma institucional. Iniciemos pela Igreja Universal do Reino de Deus.

Trata-se de uma igreja fundada em 1977 no Rio de Janeiro por Edir Macedo, sendo hoje uma instituição em constante expansão transnacional e uma potência econômica ${ }^{24}$.

Alem de atuar no campo religioso, há muito tempo a Universal opera no campo audio-visual e editorial, alem de bancário, turístico, empresarial, sempre com uma reconhecida eficiência. Ora, a mesma capacidade empreendedora e racional aplicada exitosamente em várias áreas, esta igreja também adotou no campo político, sobretudo a partir das eleições de 1994 quando deslanchou neste domínio e nele está

\footnotetext{
${ }^{24}$ Segundo a Revista Veja, de 3 de novembro de 1999, em reportagem intitulada "O milagre do caixa da Universal", informa que a Igreja Universal está hoje "à frente de um império espalhado por todo o Brasil e em outros setenta países nos quatro cantos do mundo, da Colômbia aos Estados Unidos, da África até a Rússia. A Igreja comanda uma vasta rede composta de vinte emissoras de TV e cinquenta rádios, um jornal semanal com tiragem de 1,3 milhão de exemplares dedicado a espinafrar seu maior rival, a Igreja Católica, e pelo menos uma dezena de empresas que atuam em segmentos variados, no setor financeiro, de construção civil e gráfico" (Revista Veja, 3/11/1999, p. 43).

Ainda, segundo a mesma reportagem, o patrimônio da Igreja seria de 1 bilhão de reais - colocando-se, assim, entre as 100 maiores empresas do país - e no ano de 1999 sua arrecadação poderá ultrapassar os 2 bilhões de reais (Id. Ibid., p. 38).
} 
crescendo a cada nova eleição. Por ocasião das eleições de 1998, por exemplo, a Universal conseguiu eleger 26 deputados nas assembléias legislativas dos estados (Fonseca, 1998:20). Nessas eleições a Universal elegeu, no Rio Grande do Sul, um deputado estadual e um federal, ambos pelo PTB. Na mesma ocasião elegeu 17 deputados federais (sendo 14 pastores egressos da própria igreja e 3 deputados apoiados pela igreja), contribuindo substancialmente para a formação da maior "bancada evangélica" já vista na história de nosso país com 53 deputados ligados a 13 igrejas (Revista Época, 2/10/2000).

Bispo Rodrigues, da Universal, deputado federal pelo PL, é o líder da Bancada Evangélica no Congresso Nacional, "a quarta maior bancada capaz de emperrar votações e provocar negociações com o governo, como aliás já fez" (Jornal Diário Catarinense, 30/7/2000). O poder e prestígio deste bispo-político é tal que no dia 20 de maio de 2001, por ocasião do Primeiro Encontro Liberal do Novo Milênio, realizado em Porto Alegre, ele foi lançado como candidato a Presidência da República em 2002. A executiva do partido no Estado planeja indicar o deputado federal e pastor Paulo Gouvea para disputar o governo gaúcho (Jornal Correio do Povo, 21/5/20001).

Recordo ainda que nas últimas eleições municipais do ano 2000, alem dos 2 vereadores eleitos em Porto Alegre a Universal também estreou na política municipal em muitos outros municípios do Estado do Rio Grande do Sul. Lançou 63 pastores e obreiros como candidatos a vereadores, elegendo 19 deles, uma média de $30 \%$ do total, "um índice de aproveitamento inimaginável para um partido político" (Zero Hora, 12/11/2000, p. 14) $)^{25}$.

Além do Rio Grande do Sul sabe-se que a Universal também elegeu 6 vereadores no Rio de Janeiro, formando a segunda maior bancada da câmara municipal. Em São Paulo, elegeu 4 vereadores que, juntos com outros 7 evangélicos formam a bancada evangélica composta de 11 vereadores, num

\footnotetext{
${ }^{25}$ Segundo este jornal, a Universal conquistou vagas nas Câmaras de Vereadores dos quatro maiores colégios eleitorais gaúchos (Porto Alegre, Canoas, Pelotas e Caxias do Sul), alem de vários municípios populosos da região metropolitana de Porto Alegre (Viamão, Gravataí, São Leopoldo, Alvorada, Novo Hamburgo, Cachoeirinha, Sapucaia, Guaíba, Esteio) e do interior do Estado Santa Maria, Bagé, Bento Gonçalves, Rolante e Salvador do Sul) (Zero Hora, 12/11/2000, p. 18).
} 
total de 55 que compõem o conjunto de vagas da capital paulista.

Como procede esta igreja para alcançar uma tal façanha no campo político? Ela resulta de algumas estratégias postas em prática. Com efeito, desde 1997 a Universal adotou a "candidatura oficial". Para tanto, realiza uma espécie de "recenseamento" dos seus membros/fieis no qual figuram seus dados eleitorais ${ }^{26}$. Desta maneira os dirigentes locais podem ter uma idéia aproximada do capital eleitoral de que dispõem. Alem disso, aproveitam os cultos, concentrações massivas e, especialmente, a mídia (televisão, rádio, jornal), para fazer publicidade dos seus candidatos.

Foi desta forma que em Porto Alegre os dirigentes locais da Universal, liderados pelo coordenador político da Igreja no Estado, o deputado federal Paulo Gouvea, sabedores previamente da potencialidade política que a igreja aqui detém, decidiram lançar dois candidatos a vereador. A racionalidade política da igreja foi tal que inclusive dividiram a cidade segundo os bairros e suas igrejas, que apoiaram separadamente os candidatos. O resultado, como sabemos, foi a eleição de um pastor com 10.913 votos e de outro com 7.645 votos, totalizando, juntos, 18.558 votos.

Lembramos que a candidata "independente" Veranice Neto, a única, entre os três candidatos da IURD, a enfatizar diante dos telespectadores que era "evangélica e membro da Igreja Universal do Reino de Deus", teve uma votação insignificante. Isto revela que os membros desta igreja efetuaram um voto corporativo, um "voto fiel", ou seja, seguiram à risca a orientação, indicação, dada pelos pastores, bispos e dirigentes da igreja ${ }^{27}$.

Parece, também, fazer parte da estratégia da IURD lançar os seus candidatos em diferentes partidos políticos, geralmente os maiores, embora o deputado federal e coordenador político da Igreja no Estado,

\footnotetext{
${ }^{26}$ Por ocasião das últimas eleições, a Folha de São Paulo publicou uma matéria na qual relatava uma investigação que a Justiça Eleitoral e a Policia Federal estavam realizando sobre a distribuição de folhetos em oito cidades de Minas Gerais, nos quais seu signatário se comprometia a votar em determinado pastor. Todos os candidatos que figuram no "compromisso de voto" pertenciam à Igreja Universal. (Folha de São Paulo, 28/10/2000, C4).

${ }^{27}$ Lembremos que um achado da pesquisa "Novo Nascimento", realizada pelo ISER, em 1994, foi a de que "os fiéis da Universal concentram seus votos (95\%) em candidatos da própria igreja Universal" (Fernandes et alii, 1998:146-147).
} 
Paulo Gouvea, tenha declarado para o jornal Zero Hora que a igreja não tem uma orientação quanto aos partidos aos quais seus candidatos devem se filiar. Cada um escolhe "o partido em que se sente melhor para concorrer” (Zero Hora, 12/11/2000, p. 14).

No entanto, tanto a nível federal quanto local, observamos que uma vez eleitos, alguns membros da IURD efetuam uma migração partidária. Ocorreu há dois anos atrás com Paulo Gouvea, que eleito deputado federal pelo PTB, assim que assumiu seu mandato mudou de partido, ingressando no PL, como fizeram outros pastores da Universal, entre eles o próprio Bispo Rodrigues, eleito pelo PFL. Também os 2 vereadores da IURD eleitos pelo PFL e pelo PTB para a Câmara Municipal de Porto Alegre, ingressaram no Partido Liberal. Certamente essas migrações partidárias obedecem a um cálculo político da Igreja que parece estar se apoderando do Partido Liberal. A questão a se ver é como reagem os dirigentes dos partidos que servem como "trampolim" para os candidatos da IURD. Podem considerar que vale a pena aceitar candidatos da IURD nos seus quadros, mesmo correndo o risco de sua deserção posterior, em razão dos votos que poderão carrear para a legenda partidária. Mas, podem também se opor à presença evangélica, e sobretudo da IURD em sua sigla, abandonando o partido, em sinal de protesto. É o que parece estar acontecendo com membros do diretório do PL de Canoas, na grande Porto Alegre ${ }^{28}$.

Na IURD, a escolha dos candidatos é prerrogativa única e exclusiva dos dirigentes locais (regionais) da Igreja segundo seus próprios cálculos e interesses. Não há nenhuma consulta democrática aos membros das igrejas locais. Estes recebem, no momento oportuno, o(s) nome(s) em quem devem votar. Muitas vezes, trata-se de pessoas completamente desconhecidas dos próprios irmãos de fé, que somente irão vê-los nas vésperas das eleições em razão de suas presenças nos templos, por ocasião

\footnotetext{
${ }^{28}$ De fato, segundo reportagem de Zero Hora, "o domínio da Igreja Universal do Reino de Deus sobre o Partido Liberal (PL) está motivando a desfiliação de 27 dos 29 integrantes do diretório da sigla em Canoas" (Zero Hora, 19/06/2001).

Ainda segundo a mesma matéria, movimento contestatório semelhante ao de Canoas estaria ocorrendo em outras cidades do Estado como Bagé e Rio Grande.
} 
dos cultos. Mas isto não impede que recebam os votos dos fieis, mesmo em se tratando de um candidato sem passado local, como foi o caso de Valdir Caetano, um ex-metalúrgico do $\mathrm{ABC}$ paulista que chegou a Porto Alegre há apenas três anos e meio, tornou-se pastor há um ano e meio e obteve quase onze mil votos (Zero Hora, 3/10/2000, p. 35).

Em razão deste procedimento que vigora na Universal, via de regra os seus candidatos eleitos, nos distintos níveis da política, são também sempre pessoas desconhecidas do grande publico e da imprensa especializada em política, constituindo-se "na surpresa" das eleições ${ }^{29}$.

Nas eleições 2000 em Porto Alegre, a estrutura centralizada da Universal também pôde ser vista em outro nível. Com efeito, durante o primeiro turno da campanha eleitoral, o deputado federal gaúcho da Universal e coordenador político da igreja no Estado, Paulo Gouvea, hoje filiado ao PL, compareceu no programa eleitoral gratuito na televisão da coligação "Porto Alegre é de todos", cujo candidato a prefeito era Cezar Busatto, do PMDB, para conclamar os evangélicos de Porto Alegre a votarem nele ${ }^{30}$. Ora, durante o segundo turno da campanha, como vimos, o mesmo deputado que conclamou os seus para votarem em Busatto, compareceu no vídeo, embora calado, ao lado do Bispo Rodrigues, o coordenador político mais importante da Universal, quando este conclamou os evangélicos a votarem no PT e em Tarso Genro. Neste caso, Paulo Gouvea não pôde furtar-se de emprestar ao menos a sua imagem para a propaganda do PT. Ou seja, curvou-se diante da hierarquia e da vontade do seu superior, o Bispo Rodrigues.

O que precede mostra que a Universal é um igreja que detém um forte poder centralizado e hierárquico. É uma instituição vertical cuja estrutura, organização, práticas ritualísticas e discurso, reservam pouco

\footnotetext{
${ }^{29}$ Segundo o jornal Zero Hora de 3 de outubro de 2000, a eleição do pastor da Universal Valdir Caetano, constituiu-se numa "surpresa do pleito no último Domingo" (Zero Hora, 3/10/2000, p. 35).

${ }^{30}$ Disse ele, na ocasião: "Eu gostaria de falar com todos os evangélicos do município de Porto Alegre. Me dirigir também aos pastores, ministros. Nós temos na verdade um compromisso com o bem estar da nossa sociedade. Nós que procuramos o bem estar do povo, temos que assumir também a responsabilidade com relação ao governo da nossa cidade. Porque ele é o responsável pelas pessoas; é o responsável pelo cidadão. E quantas pessoas que estão na verdade esquecidas quando um governo não dá atenção a estas pessoas. Este compromisso também é nosso em elegermos Cezar Busatto em primeiro de outubro".
} 
espaço à participação e opinião dos fiéis. Neste caso, o poder da instituição prevalece sobre a dos indivíduos. Aliás, a pesquisa intitulada Novo Nascimento, realizada pelo ISER no ano de 1994 na região metropolitana do Rio de Janeiro, já havia revelado, por exemplo, que "os fiéis da Universal praticamente ignoram (88\%) a eleição de pastores" (Fernandes et alii, 1998:59), contrariamente às igrejas evangélicas históricas, aos batistas, às igrejas renovadas e à Assembléia de Deus, onde a participação dos fiéis, naquele particular, é de 67\%,68\%, 48\% e 40\%, respectivamente. A mesma pesquisa também mostrou que entre todas as igrejas pesquisadas a Universal é a que detém o menor índice de participação dos fieis (13\%). Este índice é de $43 \%$ na Assembléia e de $45 \%$ nas Batistas ${ }^{31}$. Ora, a mesma demonstração de poder hierárquico institucional ocorre na Universal no campo político, onde os fiéis votam massissamente (95\%) nos candidatos da Igreja mais por serem indicados pela cúpula dirigente do que pelas capacidades ou qualidades pessoais dos candidatos. Vejase a grande votação alcançada em Porto Alegre pelos dois candidatos oficiais da Universal e a insignificante votação da candidata que se lançou como tal por conta própria. Isto mostra que estamos de fato diante da preeminência do carisma institucional sobre o carisma pessoal.

Outro candidato religioso eleito para a Câmara Municipal de Porto Alegre foi um leigo católico.

A Igreja Católica teve historicamente, como se sabe, uma importante presença e participação na vida política nacional. Durante o Império, entre os anos 1835 e 1837, o padre Diogo Feijó chegou a ser regente; por ocasião da Constituinte de 1823, 15 entre os 93 eleitos eram sacerdotes. Mas, a partir de 1899, com a separação igreja-estado, a igreja foi se afastando da política sendo hoje a inserção de sacerdotes na política um tema bastante controvertido e polêmico no contexto do catolicismo.

No Rio Grande do Sul, nos anos 50, houve um sacerdote que durante oito anos atuou como vereador em Caxias do Sul; um padre foi

\footnotetext{
${ }^{31}$ P. Sanchis, ao comentar a pesquisa Novo Nascimento, onde sobressaiu o poder centralizador da estrutura hierárquica da Universal, em detrimento também dos fiéis, pondera que semelhante clima reinava na Igreja Católica antes do último Concílio (Fernandes et alii, 1998:164-165).
} 
o primeiro prefeito do município de Vitória das Missões, emancipado em 1991; em 1996 um sacerdote foi eleito prefeito de Entre Rios do Sul e em 1998 um sacerdote conquistou uma cadeira na Assembléia Legislativa do Estado, fato inédito na história do parlamento gaúcho ${ }^{32}$.

Nas eleições de 2000, no Rio Grande do Sul, 8 sacerdotes católicos concorreram, sem êxito, como candidatos a vereadores, 1 deles em Porto Alegre. Diferentemente de outras religiões, o partido de filiação da maioria dos sacerdotes em questão, 5 deles, foi o PT. Trata-se de sacerdotes que trabalham em pastorais sociais e atuam em comunidades carentes ${ }^{33}$.

Mas, esse engajamento social, bem como o carisma de função (padres), não asseguraram os votos necessários para a eleição, ou seja, seu carisma de função não conseguiu provocar o reconhecimento no campo político através do voto.

Há vários elementos implicados no fracasso eleitoral dos sacerdotes católicos. Em primeiro lugar, prevalece uma forte resistência no meio católico à candidatura de sacerdotes na política. Ou seja, a idéia predominante é a de que ao padre cabem atividades de ordem espiritual e não política. Em segundo lugar, a forma organizativa da igreja católica (em dioceses, paroquias e capelas), embora seja uma ordem hierárquica, está longe de congregar os fieis que, como se sabe, não possuem vínculos religiosos capazes de unir os católicos em torno de candidaturas de sacerdotes políticos. Enfim, e não sem maior importância, a resistência da própria hierarquia católica. Ou seja, bispos do Rio Grande do Sul manifestaram-se publicamente contrários à presença de sacerdotes na política enfatizando que quando isto ocorrer eles serão aconselhados a

\footnotetext{
${ }^{32}$ De fato, durante oito anos, nos anos 50, o padre Eugênio Giordani foi eleito vereador em Caxias do Sul; o padre João Aloysio Konzen administrou o novo município de Vitoria das Missões e o sacerdote Nestor Moroni foi eleito prefeito de Entre Rios do Sul em 1996. A eleição do padre Roque Grazziotin, em 1998, pelo PT, para a Assembléia Legislativa do Estado foi um fato inédito no Rio Grande do Sul (Zero Hora, 17/09/2000, p. 5).

${ }^{33}$ Diga-se, de passagem, que o pastor Helio Pacheco, da Igreja Evangélica de Confissão Luterana no Brasil (IECLB), de Novo Hamburgo, vereador eleito em 1996 e buscando seu segundo mandato nas eleições 2000, também concorreu pelo PT. Seu lema era: "evangelizar o setor político e politizar o setor evangélico" (Zero Hora, 17/09/2000, p. 4).
} 
se afastar das atividades religiosas ${ }^{34}$.

Por sua vez, o único candidato leigo católico, socialmente reconhecido e que se identificou como tal nas eleições 2000 em Porto Alegre, se apresentou por um partido conservador (PPB) e foi eleito valendo-se do seu carisma pessoal, aliado à sua proximidade ao carisma institucional católico. É possível que parcela de eleitores católicos, de tendência conservadora, tenham preferido votar neste candidato católico, ao invés de votar nos sacerdotes que pretendem ingressar na política.

Seja como for, conclui-se que, nos dias atuais, predomina na Igreja Católica uma tendência de distanciamento da política de seus membros detentores de carisma de função (padres, bispos), contrariamente às igrejas evangélicas, pentecostais sobretudo, que estão buscando aperfeiçoar estratégias visando o ingresso e a inserção na política, sobretudo dos seus agentes religiosos.

Os demais candidatos religiosos que fracassaram nas eleições 2000 em Porto Alegre provinham de outras igrejas evangélicas e de religiões afro-brasileiras. Vejamos como elas se portaram em relação à política.

A Igreja do Evangelho Quadrangular possui cerca de $80 \mathrm{mil}$ fieis no Rio Grande do Sul e cerca de $10 \mathrm{mil} \mathrm{em} \mathrm{Porto} \mathrm{Alegre.} \mathrm{Nas}$ eleições 2000 esta igreja procedeu em parte de forma semelhante à Universal. Refiro-me ao fato de ter, também ela, adotado a "candidatura oficial” da Igreja. Assim, em todos os municípios onde a igreja está instalada realizou, como a Universal, um levantamento da sua potencialidade política, decidindo então sobre o lançamento ou não de candidatura da própria igreja, ou de apoio a outras candidaturas. Mas há, em relação à Universal, uma diferença fundamental no procedimento da Quadrangular pois enquanto naquela os candidatos aos cargos eletivos foram escolhidos pela cúpula dirigente da igreja, sem qualquer participação dos fiéis, na Quadrangular a escolha do(s) seu(s) representante(s)

\footnotetext{
${ }^{34}$ Segundo Dom José Mário Stroeher, presidente da Regional Sul 3 da Conferência Nacional dos Bispos do Brasil (CNBB), a orientação da Igreja Católica é de que os padres não se candidatem, sobretudo ao Executivo. Diz ele: "Ao se candidatar por um partido, ele toma parte de uma parcela do povo, e o pároco não deve representar apenas alguns". Por sua vez o bispo de Frederico Westphalen, Bruno Maldaner, diz: "São traidores de sua missão e prejudicam o povo de Deus" (Zero Hora, 17/09/2000, p. 6).
} 
para concorrer aos legislativos municipais foi realizada pelas comunidades religiosas mediante um processo de prévias, semelhante ao que ocorre com os partidos políticos. Ou seja, esta igreja privilegiou um procedimento democrático de escolha dos seus candidatos "oficiais". Neste caso, evidentemente que a escolha recaiu geralmente sobre indivíduos que alem do carisma de função eram considerados portadores de algum carisma pessoal. Desta forma, no Rio Grande do Sul a igreja lançou 59 candidatos a vereador, conseguindo eleger 17 deles, espalhados em todo o estado, sobretudo em municípios de porte médio ${ }^{35}$. Da mesma forma como ocorreu com a Universal, os partidos escolhidos pelos candidatos da Quadrangular foram os mais importantes do estado, tendo sido eleitos pelos seguintes partidos: PTB (7), PPB (5) PDT (3), PMDB (1) e PSDB (1). Portanto, também neste segmento religioso não houve a eleição de algum candidato pelo PT ou outro partido de esquerda.

Embora o candidato escolhido por Porto Alegre não tenha sido eleito, tendo obtido 2.333 votos, a igreja conseguiu nesta eleição eleger no Estado 8 vereadores a mais do que na última eleição (Zero Hora, 12/ $11 / 2000$, p. 18), o que mostra que de fato o novo procedimento adotado da candidatura oficial, de acordo com o capital político da igreja em cada município, surtiu algum efeito ${ }^{36}$.

Por sua vez, a Igreja Assembléia de Deus, como vimos, não conseguiu eleger nenhum dos seus quatro candidatos em Porto Alegre, em razão da distribuição dos votos entre os candidatos. Neste caso, não houve, por parte desta igreja, uma escolha prévia - seja por parte de um pequeno grupo dirigente ou dos fieis nas comunidades - de candidatos representantes da igreja. A iniciativa partiu dos próprios indivíduos de se apresentarem como candidatos. Já vimos que os dirigentes locais da igreja apoiaram sobretudo dois dos candidatos, o então vereador e pastor Eliseu Sabino e Willis Taranger, filho do pastor sueco e presidente da

\footnotetext{
${ }^{35}$ Segundo o jornal Zero Hora, a Quadrangular elegeu seus candidatos em Pelotas, Itaqui, Vacaria, Tapes, Butiá, Gaurama, Erechim, Caçapava do Sul, Cachoeira do Sul, Uruguaiana, Alegrete, Restinga Seca, São Vicente do Sul, Barra do Quaraí, Nonoai, Jóia e Triunfo (Zero Hora, 12/11/2000, p. 18).

${ }^{36}$ Esta Igreja também conseguiu eleger a vice-prefeita de Triunfo, cidade que dista 75 quilômetros de Porto Alegre.
} 
igreja até dois anos atrás. Mas, não tiveram carisma suficiente para atrair os votos dos fieis. Os dois outros candidatos fizeram juntos 2.696 votos, o suficiente para inviabilizar a eleição dos candidatos mais votados.

Há um ano atrás, o vereador Eliseu Sabino, já temendo a multiplicação dos candidatos da Igreja realizava articulações no sentido de sair novamente, tal como ocorreu por ocasião das eleições de 1996, como candidato único da igreja. Em entrevista ${ }^{37}$ dizia estar "buscando isto (ser candidato único da igreja) de novo pra reeleição. Estou trabalhando nisso pra que eu saia como um candidato de consenso. Se isto ocorrer, sempre intimida alguns outros, né, isto é estratégia política...".

$\mathrm{O}$ insucesso na sua empreitada deve-se, ao menos em parte, à própria estrutura organizacional da Assembléia de Deus. Com efeito, esta Igreja está organizada segundo um modelo de governo congregacionalista, que supõe autonomia e independência, ao menos relativa, das igrejas, congregações e pontos de oração/pregação. Cada igreja, ou congregação, vincula-se a distritos administrativos e estes a uma sede local. Há, portanto, uma hierarquia mas não autoritária na medida em que as igrejas locais são também autônomas. É neste contexto que emergem, dentro de igrejas locais, indivíduos cidadãos que se lançam como candidatos, não tendo o grupo dirigente poder para dissuadi-los da idéia. Neste sentido, é interessante o depoimento do pastor João Ferreira Filho, presidente da Assembléia de Deus de Porto Alegre e do Estado do Rio Grande do Sul. Disse ele: "Eu abri meu voto para o (...), imaginando que iriam me seguir. Não foi o que ocorreu”, ao que completou: "nosso povo (assembleiano) é bastante unido na religião, mas não na política”.

Como se vê, a Assembléia de Deus procedeu diferentemente da Universal e da Quadrangular. A cúpula dirigente não propôs (impôs) candidatos, como fez a Universal, nem realizou uma votação prévia dentro da igreja para indicar seus representantes, como fez a Quadrangular. De fato, a Assembléia não optou pela candidatura oficial embora, em Porto

${ }^{37}$ Concedida em 19/05/1999 a Débora Leitão, então minha bolsista PIBIC/CNPq. 
Alegre, seus dirigentes tenham emprestado seu apoio a dois dos candidatos da igreja que se lançaram como tais. A iniciativa de candidatarse partiu dos próprios membros da igreja. $\mathrm{O}$ resultado disso foi a diluição do capital político entre os candidatos com um resultado negativo para a igreja pois não elegeu nenhum seu representante e, assim, perdeu a cadeira no legislativo municipal, ocupada por Eliseu Sabino.

No âmbito desta igreja, portanto, o carisma de função (pastor) não mostrou-se suficiente, no campo político, para obter a confirmação do voto, o que sugere ter o carisma pessoal dos sujeitos candidatos a cargos eletivos, mesmo de pastores, um peso significativo, ao lado do carisma de função (pastores).

No entanto, esta Igreja está pensando em assumir para si o controle institucional nas próximas eleições. Com efeito, a cúpula dirigente da Assembléia de Deus está também articulando a idéia da implantação nas eleições vindouras da "candidatura oficial" da igreja, tanto para o legislativo municipal quanto para o estadual, resultante de um estudo prévio da potencialidade política da igreja em cada município e no estado. Neste sentido, o presidente geral da igreja disse "admirar bastante" a forma como a Universal se articula politicamente. Considerou porem mais adequado o modelo adotado pela Quadrangular de escolha prévia dos candidatos, ou seja, escolha com a participação dos fieis e não imposição vertical dos candidatos.

As igrejas Batista Filadélfia e Adventista do Sétimo Dia também estão organizadas em igrejas e grupos locais relativamente autônomos. Essas denominações não lançaram candidatos oficiais nem empreenderam uma análise anterior do capital político de que dispõem. Sua visibilidade televisiva nas últimas eleições proveio dos próprios candidatos que reivindicaram o seu pertencimento a essas igrejas em razão de suas próprias iniciativas de se lançarem na política e explorarem a condição de membros dessas igrejas imaginando com isto poderem aumentar a sua votação.

Trata-se, pois, também, de instituições em que o carisma de função não é garantia de votos, como ocorre na Universal. É preciso contar com forte carisma pessoal para obter eficácia política. 
Revendo a história das religiões afro-brasileiras no Rio Grande do Sul, vê-se que já houve participação de seus representantes na esfera política. Com efeito, o babalorixá Custodio Almeida, um príncipe africano, da região do Benin, que residiu em Porto Alegre de 1901 a 1935 (data do seu falecimento), se tornou, em seu tempo, uma espécie de guru de importantes políticos, frequentando o palácio dos Presidentes do Estado e sendo por eles procurado para atuar religiosamente (Nunes da Silva, 1999).

No ano de 1960 o umbandista Moab Caldas foi eleito para a Assembléia Legislativa do Estado, pelo PTB de Leonel Brizola e Jango Goulart, e re-eleito nos anos de 1964 e 1968. Foi cassado em 1968, vindo a falecer em $1997^{38}$. Também no ano de 1960 foram eleitos três prefeitos umbandistas e cerca de 20 vereadores no Rio Grande do Sul.

Após este período, não parece ter havido mais presença efetiva de membros desta religião em cargos eletivos no Rio Grande do Sul, malgrado algumas tentativas, como a de Ailton Albuquerque, renomado pai-de-santo de Porto Alegre que se apresentou às eleições legislativas gaúchas nas últimas eleições de 1998 pelo Partido Trabalhista Brasileiro (TPB). Não logrou se eleger, tendo obtido 3.425 votos.

Nas eleições de 2000 não consta ter havido algum líder desta religião que tenha sido eleito em algum município do Rio Grande do Sul. Em Porto Alegre, como vimos, os quatro babalorixás candidatos foram derrotados, bem como o presidente de um respeitado terreiro. Juntos, não fizeram votos suficientes para eleger um único candidato.

$\mathrm{O}$ discurso eleitoral proposto pelos quatro pais-de-santo para dentro da "comunidade" afro-umbandista era fundamentalmente o mesmo: a necessidade da "religião" ter representantes no legislativo municipal para defender os seus direitos e para mostrar sua força perante a sociedade e, sobretudo, perante os evangélicos e, destes, os pentecostais, que estão

\footnotetext{
${ }^{38}$ Diana Brown recorda que em 1960 os umbandistas também elegeram para a Assembléia Legislativa do Rio de Janeiro Atila Nunes - um radialista umbandista que havia sido eleito vereador em 1958 (Brown, 1985).

Maria Helena Villas Boas Concone e Lísias Nogueira Negrão fazem uma análise histórica dos distintos momentos da relação da umbanda com a política e o Estado, onde prevaleceu a perseguição até o golpe de 1964 e a sua cooptação política a partir de então. Mais especificamente analisam o envolvimento político-partidário da umbanda paulista nas eleições de 1982 e analisam a derrota dos candidatos umbandistas (Concone e Negrão, 1985).
} 
ampliando seu espaço na política e se mostrando abertamente críticos em relação às religiões afro-brasileiras. Ora, este discurso não produziu a eficácia esperada pelos candidatos e, a meu ver, isto se deve, também, à própria estrutura e ao ethos das religiões afro-brasileiras.

Com efeito, o modelo organizacional das religiões afro-brasileiras repousa sobre uma variedade de federações e uma pulverização de terreiros, sendo todos ao mesmo tempo autônomos e rivais entre si. Não existe, no âmbito desta religião, uma única hierarquia religiosa; não dispõem de um poder centralizador e aglutinador dos centros religiosos. Estes, ao contrário, são autônomos e, por isso mesmo, concorrentes entre si. Em consequência disso, reconhece o candidato a vereador Jorge Verardi, presidente da Afrobras, "cada um procura sua própria autopromoção"; "não temos a organização dos aleluia”, disse uma mãe-de-santo.

Ora, este ethos constituído de permanente disputa, rivalidade entre terreiros e desqualificação do outro, torna, como reconhece R. Prandi, bastante remota a possibilidade de união entre terreiros e grupos, mesmo em se tratando de proveito para a religião (Prandi, 1991:163) ${ }^{39}$.

É a partir desta situação que se pode interpretar o fracasso eleitoral dos candidatos sacerdotes das religiões afro-brasileiras. Embora houvesse uma lógica em seu discurso (demonstrar socialmente a "força da religião" e unir-se para fazer frente aos ataques de algumas igrejas pentecostais), ela não logrou superar o modo de ser competitivo que prevalece neste meio religioso. Ou seja, no âmbito das religiões afro-brasileiras prevalece exclusivamente o carisma pessoal, e este não foi suficiente para garantir a eleição de nenhum candidato. Suspeito que cada pai-de-santo candidato dificilmente colheu votos para alem da sua rede religiosa, ou seja, dos eleitores dos seus próprios terreiros e daqueles com os quais cada um deles mantinha uma relação de aliança à época da eleição.

Resumindo este item podemos perceber a existência de um continuиm das religiões e igrejas apresentadas e sua relação com a política. Encontramos,

\footnotetext{
${ }^{39}$ No entanto, não estamos emitindo nenhum juízo de valor sobre este permanente conflito entre líderes de terreiros das religiões afro-brasileiras. Há mesmo alguns autores, como N. Correa que, baseado em G. Simmel, levanta a hipótese de que o conflito referido não representa algo negativo na vida social dessas religiões posto que ele constitui a chave para explicar a permanência histórica e o crescimento das religiões afro-brasileiras, em razão do seu papel também construtivo e agregador em termos sociais (Correa, 1998).
} 
de um lado, a Universal e seu poder centralizador, hierárquico, autoritário e não participativo, onde prevalece o carisma institucional, cujo efeito na política foi, em Porto Alegre, a eleição dos dois candidatos lançados pela igreja.

Evidentemente que para alcançar a eficácia política e assegurar o seu carisma institucional, a Universal valeu-se de suas especificidades, fez uso de um know-how historicamente construído e sedimentado ${ }^{40}$ e trouxe para o campo político o seu estilo aguerrido. Aliás, a capacidade mobilizadora da igreja é tão grande que a pesquisa Novo Nascimento mostrou serem os fieis da Universal, entre todos os evangélicos pesquisados, os que mais oram para os seus candidatos (para vencerem) e os que mais se engajam na política (colocando cartazes e distribuindo "santinhos", por exemplo).

O resultado do poder carismático da Universal é tal que nesta denominação religiosa o ato de votar passa a ser concebido como um ato que preenche um sentido quasi-religioso, na medida em que ele se torna uma espécie de exorcismo do demônio que se encontra na política para que esta seja um espaço "liberto" e ocupado por "pessoas tementes a Deus", segundo o jargão evangélico. Em outras palavras, o efeito de sentido produzido pelo discurso e pelo carisma da IURD por ocasião do período que precede as eleições é tal que os seus fiéis acrescentam um sentido a mais ao ato de votar além do dever cívico, na medida em que o gesto de votar assume o significado de um rechaço do mal que se instalou na política e sua substituição pelo poder do bem, introduzindo nele, mediante o voto, pessoas convertidas ao evangelho ${ }^{41}$.

\footnotetext{
${ }^{40}$ Refiro-me a determinados procedimentos que visam mostrar a "grandeza" e as particularidades da Igreja tais como: reunir seus fieis em templos/igrejas bastante espaçosos (antigos cinemas e fábricas ou edificações expressamente construídas para tanto que comportam milhares de pessoas), provocar o rodízio frequente de pastores (cuja lógica é evitar que os fieis se apeguem às pessoas e não à Igreja, alem de mostrar a quantidade de pastores que a mesma detém), diversificação e criatividade na promoção de "campanhas" diversas, performance ritualística com grandes efeitos emocionais; êxito na interpelação do "demônio" e a libertação do mesmo com reflexos positivos na vida dos seus fieis; entusiasmo dos pastores em discursos próximos à perspectiva da auto-ajuda e da neurolinguística. A tudo isto agrega-se o importante uso da mídia, eletrônica e escrita, e o assistencialismo social, como vimos acima.

${ }^{41}$ Unm prática comum dos membros da IURD vem em apoio a este argumento. Consiste em estampar, grudar, na capa de suas bíblias, o "santinho" (fotografia publicitária) do candidato da igreja a quem vão destinar seus votos.

Igualmente, é comum se ver estampado nas paredes dos interiores dos templos da Universal, no período que antecede as eleições, cartazes e panfletos dos seus candidatos.
} 
Assim sendo, fica implícito, também, que votar, para os fieis da Universal, consiste na expressão de sua relação identitária com a Igreja mais do que com qualquer partido político. Ou, então, a própria igreja torna-se o seu partido. Este fato condiz com a concepção prevalecente na cultura brasileira, onde, segundo M. Palmeira, "o voto não é associado ao exercício de um direito individual, mas a uma sinalização de adesão a um 'lado' (facção) da sociedade" (Palmeira, 2000:11).

$\mathrm{Na}$ outra ponta do continnum se encontram as religiões afrobrasileiras, destituídas de poder hierárquico centralizador e existindo total autonomia das unidades locais (terreiros). Estes aglutinam-se em redes precárias e no seu conjunto geralmente são desunidos e cultivam a rivalidade entre si. Em consequência disso, no âmbito político haveria quase ausência de eficácia do carisma de função (votar em alguém por ser pai-de-santo) e quase exclusivo reconhecimento (mediante o voto) do carisma pessoal de um pai-de-santo que, por suas qualidades e dons pessoais, teria conquistado status e prestígio capaz de amalhear votos dos que assim o consideram.

Evidentemente que a própria característica das religiões afrobrasileiras, voltadas mais para o atendimento individualista, a satisfação de demandas particulares, sem cultivar um projeto social mais amplo, com implicações políticas, possui sua implicação na dificuldade das mesmas conseguirem eleger representantes seus em cargos políticos.

E, no meio do continuum, se encontram as igrejas que adotam um modelo congregacionalista, federativo e representativo (tipo Assembléia de Deus, Quadrangular, Batista, Adventista e, também, católica). Nelas haveria, de um lado, algum grau de autonomia e independência das unidades locais (paróquias, igrejas, capelas, congregações, distritos) e uma relativa delegação dos fieis aos pastores e dirigentes de representálos e tomar decisões em seu nome. De outro lado, haveria nelas uma relação de complementariedade ou de oposição, dependendo das situações e das instituiçõos, entre carisma de função e carisma pessoal, ora prevalecendo um ora outro, dependendo de circunstâncias e situações próprias a cada caso. No campo político, por ocasião das últimas eleições em Porto Alegre, este modelo tem obtido um efeito relativamente inócuo. 
Talvez seja por isso que, por exemplo, a Assembléia de Deus esteja tentando imitar a IURD, ao menos em parte, para viabilizar seus próprios projetos de inserção no campo político.

\section{A ética, a Universal e o PT}

Um outro aspecto que merece ser destacado nas eleições $2000 \mathrm{em}$ Porto Alegre foi o apoio explícito dado ao PT pela Igreja Universal durante a campanha do segundo turno. Este fato parecia paradoxal se se levasse em conta o fato de que os dois candidatos a vereadores desta Igreja, eleitos no dia 1 de outubro para a Câmara Municipal de Porto Alegre, eram filiados a dois partidos (PTB e PFL) que no segundo turno se aliaram contra a Frente Popular. Hoje pode-se inferir que aquele apoio fazia sentido, tanto assim que atualmente, como vimos, ambos os vereadores da Universal aliaram-se à base governista na Câmara Municipal.

Por ocasião da campanha eleitoral, a adesão da Universal a Tarso foi noticiada no jornal Zero Hora do dia 21 de outubro, em sua pagina 4, que estampou a seguinte manchete: "Universal apóia Tarso". A reportagem esclarecia que os deputados Bispo Rodrigues e pastor Paulo Gouveia, ambos do Partido Liberal (PL) ${ }^{42}$ - partido que no Rio Grande do Sul uniuse ao PMDB na coligação "Porto Alegre é de todos" - declararam o seu apoio ao PT. Isto significa que embora o PL tivesse se posicionado no Rio Grande do Sul contra o PT, os coordenadores políticos da IURD (Rodrigues a nível nacional e Gouvea a nível estadual), hipotecaram publicamente seu apoio a Tarso Genro, do PT. Isto reforça o que dissemos acima, a saber, que o vínculo partidário na IURD é secundário, os interesses e as orientações da Igreja estando acima dos partidários.

Sublinho que se a larga margem de votos obtidos por Tarso Genro em Porto Alegre em relação ao seu rival no segundo turno encobre o apoio recebido da IURD, o mesmo não parece ser o caso em Caxias do Sul, cidade da Serra

\footnotetext{
${ }^{42}$ Recordo que Bispo Rodrigues é atualmente o vice-líder do PL na Câmara de Deputados e Paulo Gouvea é conselheiro do mesmo partido na Câmara Federal.
} 
Gaúcha, cujo prefeito, Pepe Vargas, também do PT, concorria à re-eleição em segundo turno, e recebeu o mesmo apoio público da dupla de deputados da IURD acima mencionados. Ora, Vargas venceu seu oponente José Ivo Sartori, do PMDB, por apenas 824 votos de diferença. Aqui, por certo, o apoio dos eleitores da Universal foi decisivo para a eleição do prefeito do PT uma vez que, de um lado, a IURD estima possuir cerca de três mil fiéis em Caxias do Sul e, de outro lado, as pesquisas terem mostrado que a IURD consegue um altíssimo índice (95\%) de "voto fiel" (Fernandes et alii, 1998).

Esta situação dá plena razão à afirmação, quase um alerta, de Joanildo Burity: "Os partidos e candidatos que não levam em consideração os grupos religiosos em seu discurso e estratégia correm sério risco de se complicarem ou inviabilizarem eleitoralmente” (Burity, 1997:46).

Em seus pronunciamentos pedindo votos ao PT, não somente dos membros da IURD mas também de todos os evangélicos, Bispo Rodrigues enalteceu o trabalho social desenvolvido por aquele partido bem como sua "ética em governar". "Vote em quem governa com ética. Vote no PT", afirmou ele, enfaticamente. Isto subentende que a Universal preconiza a ética na política. Aliás, é o que afirma diretamente o candidato a vereador da Universal, como vimos, quando diz: "Entendo que a política tem que ser ética". Este último aspecto merece ser aprofundado.

Com efeito, o discurso político da IURD em particular, e das igrejas pentecostais em geral, apontam para a necessidade de se implantar no Brasil uma nova moral pública e uma nova ética na política, o que poderá ocorrer somente se forem eleitos "homens e mulheres tementes ao Senhor Jesus", (subentende-se evangélicos), segundo as palavras de Bispo Rodrigues $^{43}$, que acrescenta poder os evangélicos contribuir com a eleição mesmo de governantes de $\operatorname{estados}^{44}$. Segundo o sociólogo e teólogo

\footnotetext{
${ }^{43}$ Eis todo o pronunciamento de Bispo Rodrigues: "Conclamo o povo de Deus a que nos unamos em torno dos nossos ideais e não tenhamos medo de participar do processo político, elegendo homens e mulheres tementes ao Senhor Jesus a fim de que nossa sociedade seja transformada e possa ser orientada, segundo os verdadeiros princípios cristãos" (In: Jornal Folha Universal, 6/08/2000).

${ }^{44}$ Por exemplo: o jornal Folha Universal, edição N. 396, de 16/11/99, numa reportagem em que dava conta de um jantar que reuniu vários evangélicos com o governador do Rio de Janeiro (também ele evangélico, afirma que "os deputados deixaram claro o desejo (...) unânime segundo o qual os políticos cristãos tornem-se símbolos nacionais mostrando assim que o "Povo de Deus" está em condições de governar não somente o Estado (do Rio de Janeiro) mas também o país".
} 
metodista Leonildo Campos, o sonho de um novo começo social, de uma reconstrução sociopolítica, vigora no conjunto do protestantismo brasileiro e se expressa nesta quase palavra de ordem: "O Brasil será um país diferente quando à sua frente estiver um homem de Deus" (Campos, 2000:21). Esta utopia terrena acompanha a mudança de mentalidade que atualmente alcança parte importante dos evangélicos relativamente ao milenarismo, não mais projetado para o alem e o futuro mas para aqui (na terra) e agora.

A veiculação deste tipo de discurso que redimensiona o princípio milenarista entre os pentecostais tem aumentado nos últimos anos na exata proporção em que a imprensa nacional noticia os esquemas de corrupção e desvio de recursos públicos. Por isso mesmo, para estes segmentos religiosos a corrupção constitui a antítese dos princípios cristãos de valorização da comunidade, do bem comum, da fraternidade, vindo a constituir-se no principal inimigo do bem estar dos cidadãos, justificando e legitimando assim o ingresso dos "crentes" na política uma vez que se consideram uma espécie de "reserva moral" da sociedade. Em outras palavras, como disse em outro lugar (Oro, 2001), quanto mais vem a público notícias que dão conta da impunidade de políticos corruptos e a malversação do dinheiro público, mais algumas parcelas evangélicas (entre elas a Universal) se atribuem a missão de imprimir valores evangélicos, cristãos, na política.

Mas, semelhante apelo pela ética na política que provem das igrejas pentecostais (sobretudo da IURD), também é encontrado no discurso político dos lideres do PT. Com efeito, uma tônica dos discursos de campanha do PT em todo o Brasil, durante as eleições de 2000, consistiu tanto na denúncia contra a falta de ética por parte de governantes e políticos que atualmente dão sustentação política ao governo federal quanto na reivindicação de uma conduta política moral inatacável. Tanto assim, diz Lula, "que passamos por essa campanha (de 2000) sem sermos alvos de uma única denúncia de corrupção" (Isto É, 8/11/2000, p. 4).

Assim sendo, constatamos uma afinidade discursiva entre a Universal e o PT pela "purificação da política", pela "ética na política", constituindo-se este o principal elemento de encontro e aproximação daquele partido com esta igreja e sua representação política nas eleições 
de $2000^{45}$. São, no entanto, diferentes as razões simbólicas do partido e da igreja em relação à defesa da ética na política.

Com efeito, para o PT, trata-se de um principio de respeito e valorização da cidadania, os políticos sendo os gestores da coisa pública (e não de interesses pessoais ou corporativos) que deverão cumpri-la com seriedade, transparência, justiça social e participação popular. Alem disso, via de regra os eleitores do PT tendem a cumprir este ato de cidadania num contexto de racionalidade diferente daquela que prevalece entre os eleitores da Universal.

De fato, para a IURD, a batalha pela moralização enquadra-se no âmbito da batalha espiritual que abre espaço para um discurso que apela diretamente para "forças invisíveis" atuando na política. Em outras palavras, se a política é "suja", "corrupta", "desonesta", é porque o demônio está atuando nela. Assim sendo, a IURD traz para o campo político a mesma ideologia da demonização que constitui o eixo sobre o qual nesta igreja repousa seu universo simbólico (Barros, 1995).

Este recurso às forças invisíveis não representa, porém, um esgotamento da racionalidade política mas uma continuação e um diálogo que esta igreja em particular e o pentecostalismo em geral mantém com o universo religioso dominante junto às camadas populares brasileiras (e latino-americanas), as quais, segundo L. F. D. Duarte, são portadoras de uma mentalidade cosmológica que supõe "uma relação estreita entre a Pessoa, a Natureza e a Sobrenatureza” (Duarte, 1986:248) e que concebe o sagrado enquanto fundamento do social.

No entanto, esse discurso pela moralização da política que, nas eleições de 2000 aproximou PT e IURD, não pode ofuscar as sabidas diferenças existentes entre as duas instituições sobretudo no que se refere aos objetivos e interesses de uma e outra bem como ao espaço reservado à democracia no interior das mesmas e na relação com a sociedade em

\footnotetext{
${ }^{45}$ Além da ênfase na ética, poderia-se ver outro ponto de encontro entre Universal e o PT no uso reiterado do termo cidadania que seus membros usam. Sendo este um termo "marca registrada" do PT, não deixa também de chamar a atenção o fato, por exemplo, de o candidato a vereador da Universal de Porto Alegre, candidato pelo PTB, em suas aparições no horário de propaganda eleitoral gratuita na televisão, tenha repetido: "trabalho pela nossa cidadania", e "tenho trabalhado na obra social de afirmação de valores da cidadania...". Este é um discurso "típico" dos candidatos do PT.
} 
geral. E, principalmente, o discurso de moralização da política, presente nos dois discursos, precisa ser visto como um componente do imaginário político destas instituiçõos que não garante sua efetivação empírica. Por isso, merece ser indagado se sua prática política está plenamente isenta do vírus da corrupção e da preeminência dos interesses pessoais e corporativos.

Lembro, justamente, a propósito da Universal, que seu fundador, Edir Macedo, esteve preso durante dez dias em 1992 acusado de estelionato, charlatanismo e curandeirismo. Noto, ainda, que uma das imagens públicas que prevalece em nossa sociedade sobre a Universal é o seu comportamento anti-ético, resultante da forma como trata com a questão do dinheiro, da cura, da relação com as religiões afro-brasileiras. Enfim, o fazer política da Universal não deixa de contemplar alianças com vistas a interesses da igreja, como ocorreu no apoio por ocasião da reeleição de Fernando Henrique Cardoso, mediante a troca de verbas para entidades sociais da Igreja (Jornal Folha de São Paulo, 26/07/1998).

Obviamente, não é somente a Universal que mantém um discurso pela ética na política mas que na prática tende a reproduzir o modelo de práxis política recorrente no país. A este propósito, Ricardo Mariano sublinha que na Constituinte e nas legislaturas subsequentes, os políticos pentecostais "embora se vangloriassem como guardiões da moralidade pública e se vissem como "sal da terra", "luz do mundo", representantes de Deus", vários parlamentares pentecostais, membros de igrejas e partidos conservadores, protagonizaram escândalos variados de malversação de recursos públicos e revelaram possuir uma voracidade fisiológica que em nada diferia da dos piores de seus pares não crentes. Deram mau "testemunho", passando a impressão de que a maioria deles concebe a política tão-somente como meio de reforçar seu poder no interior de suas denominações e como artifício para obter benefícios e dividendos próprios ou, na condição de despachantes de igreja, para atender aos interesses e às demandas corporativas de suas organizações religiosas, que cada vez mais enveredam no mundo dos negócios" (Mariano, 2001:13-14).

Por isso mesmo, L. Campos questiona, ao mesmo tempo em que sugere, implicitamente, uma resposta: "Seria a corrupção de políticos 
evangélicos uma demonstração da afinidade eletiva entre pentecostalismo e cultura política autoritária, que tradicionalmente tem predominado na América Latina?” (Campos, 2000:23).

\section{Conclusão}

A análise feita sobre a articulação entre o religioso e o político por ocasião da campanha eleitoral do ano 2000 em Porto Alegre, que visava o preenchimento de cargos para o executivo e o legislativo municipal, permite-nos encaminhar três idéias, menos conclusivas e mais tendenciais.

Em primeiro lugar, se, de um lado, em Porto Alegre, como de resto em nosso país e alhures, é evidente a receptividade do processo de secularização enquanto separação entre religião e política - esta última, em certa medida, independizando-se e autonomizando-se em relação à primeira - de outro lado nota-se porém que na prática e na atualidade os campos político e religioso continuam a combinar-se e a infuenciar-se mutuamente sobretudo por ocasião do "tempo da política" (Palmeira, 2000), ou seja, do período da campanha eleitoral propriamente dita. Neste momento vimos que em Porto Alegre alguns partidos e coligações que cobiçavam o executivo municipal tentaram, uns mais outros menos, se aproximar do campo religioso, uma coligação inserindo a palavra "cristã" em sua sigla de campanha, para, desta forma, tentar cativar todos os quantos se identificam com esse sistema religioso; outra coligação sendo composta por políticos que detém uma vinculação religiosa; outra, ainda, aceitando e veiculando abertamente o apoio recebido de diferentes líderes religiosos. Isto mostra que na perspectiva de muitos políticos e partidos, a religião e os valores religiosos não podem ser desprezados e sua apropriação discursiva visa produzir efeitos de sentido junto aos eleitores portadores de mentalidade religiosa.

Vimos também que nas eleições 2000 de Porto Alegre um certo número de candidatos ao legislativo municipal apresentaram-se como agentes religiosos, membros de uma determinada igreja ou religião. Em comum, entre eles, a construção de articulações de sentido entre o 
religioso e o político. Tais candidatos religiosos provem, em sua maioria, de campos institucionais não católicos, o que revela estar de fato instalada entre nós a diversidade religiosa também no campo político.

Isto nos conduz a afirmar que em nosso meio a secularização, ao mesmo tempo em que pode ser vista como autonomização do profano e do político em relação ao religioso, pode também ser percebida como recomposição do campo religioso - relacionada às mudanças que envolvem a própria sociedade, na perspectiva apontada por D. HervieuLéger (1985) - que chega ao ponto de produzir novas combinações e novas articulações do religioso com o político. Não parece porem ser passível de conclusão uma relação obrigatória e mesmo de afinidade entre determinadas religiões e certos partidos ou tendências políticas. A complexidade é tal que várias composições são possíveis neste campo.

Em segundo lugar, vimos como o ingresso de algumas igrejas e atores religiosos na política foi preparada e precedida por ações de assistência social. Andre Corten, entre outros autores, já havia sublinhado em relação às igrejas pentecostais latino-americanas, que “... as obras assistenciais permitem (às igrejas pentecostais) de se constituir uma base eleitoral" (Corten, 1997:29). Este autor chama este fenômeno de "neoclientelismo", ou "sub-clientelismo", uma vez que, contrariamente ao clientelismo tradicional, as relações não se desenvolvem na linha vertical mas horizontal, ou seja, elas não chegam às camadas superiores da sociedade (Corten, 1997).

No entanto, merece ser esclarecido que não são somente as igrejas pentecostais ou alguns sacerdotes de religiões afro-brasileiras que se valem do assistencialismo, ou do clientelismo, como ante-sala do político. Direta ou indiretamente também assim procedem outras expressões religiosas, inclusive a católica. Ou seja, neste ponto os agentes e líderes religiosos tendem a reproduzir um componente que constitui quase uma marca da sociedade brasileira, isto é, o fazer político baseado em ações paternalistas e clientelistas que subentende a troca de favores entre políticos e seus eleitores. Merece pois ser também destacado que ainda hoje a prática assistencialista consiste num procedimento reproduzido pelos políticos e partidos, de direita e de esquerda, embora em graus variados, evidentemente. 
Em terceiro lugar, vimos que a estrutura das organizações religiosas e seu grau de mobilização em relação à política teve um grande peso para o sucesso ou o fracasso eleitoral dos seus membros, muito mais do que o numero de vezes que os candidatos compareceram no vídeo ou do tipo de discurso que proferiram durante a campanha eleitoral no programa eleitoral gratuito na televisão. Ou seja, observamos que o êxito político da Universal deveu-se tanto à sua estrutura eclesial carismática, centralizada e não participativa, segundo a tipologia das estruturas eclesiais proposta por P. Carneiro (Carneiro, 1998) ${ }^{46}$, quanto ao seu real interesse de ingresso e participação no campo político, tendo ela acionado, para tanto, todos os mecanismos, estruturais e simbólicos, de que dispõe, associado a uma racionalidade política.

Também foi parcialmente exitosa a igreja católica, mas de forma indireta, uma vez que enquanto instituição não se inseriu na política; ao contrário, tendeu a distanciar-se dela, tanto assim que não apoiou oficialmente os seus sacerdotes candidatos. Neste caso, a eleição do candidato católico leigo deveu-se sobretudo ao seu carisma pessoal, associado ao reconhecimento da sua condição de católico, "cristão, na palavra e na ação", conforme suas próprias palavras repetidas durante a campanha eleitoral.

Não lograram sucesso político as demais igrejas evangélicas e/ ou pentecostais (mais ou menos institucionalizadas) que não assumiram efetivamente o interesse pela política enquanto uma decisão institucional e que possuem uma forma organizacional que assegura relativa autonomia ao local e relativa participação dos fiéis nos destinos das instituições.

Enfim, também não obtiveram sucesso as religiões afro-brasileiras, cujo poder está fortemente descentralizado, prevalecendo a oposição e a rivalidade entre as unidades locais (terreiros e federações), que não encontram ambiente para firmar alianças em torno de alguns candidatos capazes de levá-los à eleição.

\footnotetext{
${ }^{46}$ Isto é, uma instituição onde "o carisma apresenta-se como o único elemento de organização do poder, da igreja local à organização nacional, constituindo um espaço institucional pouco propício à participação dos fieis nos assuntos da Igreja" (Carneiro, 1998:187).
} 
O sucesso político da Universal não passa desapercebido pelas outras denominações evangélicas e outras religiões. Por isso mesmo, ela vem produzindo um efeito mimético de mobilização de outras igrejas que também pretendem mostrar socialmente o seu capital político. Este, como já disse em outro artigo (Oro e Semán, 1997), talvez seja, ao menos por enquanto, o maior efeito do êxito político da Universal, em Porto Alegre, no Rio Grande do Sul e no resto do Brasil: o de influenciar mais o campo religioso e menos o campo político propriamente dito, na medida em que está conduzindo, e mesmo forçando, outros lideres de outras religiões não somente a se engajarem na política mas também a adotarem o "modelo" Universal de nela atuar. Isto não quer dizer, porém, que as bancadas evangélicas, locais, estaduais ou nacional, não disponham hoje de um poder político que possa ser desprezado pelos partidos políticos especialmente nos momentos de alianças e composições.

Além disso, parece também ser hoje o caso de que a presença, que se acentua a cada nova eleição, de diferentes organizações religiosas na política, tem produzido uma maior participação e mobilização de algumas parcelas da sociedade na política, ao menos durante o "tempo da política", engajamento este que, não fosse pelo viés religioso, talvez os partidos políticos não tivessem conseguido alcançar.

\section{Referências Bibliográficas}

ANTONIAZZI, A. et alii. Nem anjos nem demônios: interpretações sociológicas do pentecostalismo. Petrópolis, Vozes, 1994.

BARDIN, Laurence. Análise de Conteúdo. Lisboa, Edições 70, 1977.

BARROS, Mônica do Nascimento. "A batalha do Armagedom”. Uma análise do repertório mágico-religioso proposto pela Igreja Universal do Reino de Deus. Dissertação de Mestrado, UFMG, Belo Horizonte, 1995.

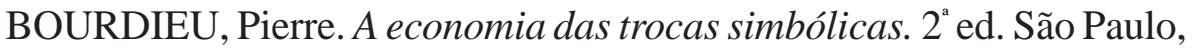
Editora Perspectiva, 1987. 
BROWN, Diana. "Uma história da Umbanda no Rio. In: Umbanda e Política”. Cadernos do ISER. N. 18, 1985:9-42.

BURITY, Joanildo. Identidade e Política no Campo Religioso. Recife, IPESPE, Editora Universitária/UFPE, 1997.

CAMPOS, Leonildo Silveira. "Composições e recomposições do poder espiritual e político". In: Tempo e Presença. Ano 22, N. 313, setembro/outubro 2000:20-23.

CARNEIRO, Leandro Piquet. "Cultura Cívica e Participação Política entre Evangélicos". In: FERNANDES et alii. Novo Nascimento. Os evangélicos em casa, na Igreja e na Política. Rio de Janeiro, Mauad, 1998:81-210.

CONCONE, Maria Helena Villas Boas \& NEGRÃO, Lísias Nogueira. "Umbanda: da repressão à cooptação. O envolvimento político partidário da umbanda paulista nas eleições de 1982”. In: Umbanda e Política. Cadernos do ISER. N. 18, 1985:43-79.

CORREA, Norton Figueiredo. Sob o signo da ameaça: conflito, poder e feitiço nas religiões afro-brasileiras. Tese de doutorado defendida na PUC/SP em dezembro de 1998.

CORTEN, André. Os pobres e o Espírito Santo. O Pentecostalismo no Brasil. Petrópolis, Vozes, 1996.

CORTEN, André. "Pentecôtisme et politique en Amérique latine". In: Problèmes d'Amérique Latine. N. 24, jan-março 1997:17-32.

DEBATES DO NER. Dossiê "Guerra Santa”. Porto Alegre, PPGAS, ano 1, n. 1, 1997.

DUARTE, Luiz Fernando D. Da vida nervosa nas classes trabalhadoras urbanas. Rio de Janeiro, Jorge Zahar Ed./CNPq, 1986.

FERNANDES, R. C. et alii. Novo Nascimento. Os evangélicos em casa, na Igreja e na Política. Rio de Janeiro, Mauad, 1998.

FONSECA, Alexandre Brasil. "A maior bancada evangélica”. In: Tempo e Presença. São Paulo, Cedi, N. 302, novembro/dezembro de 1998:20-23.

FRESTON, Paul. Protestantes e política no Brasil. Da Constituinte ao impeachment. Campinas, Unicamp. 1993 (tese de doutorado). 
HERVIEU-LÉGER, Danièle, Vers un nouveau Christianisme? Paris, Cerf, 1985.

JORNAL ZERO HORA, RBS, Porto Alegre, edições de 17/09/2000, 03/10/2000, 21/10/2000, 12/11/2000, 01/05/2001, 19/06/2001.

JORNAL FOLHA DE SÃO PAULO, edições de 26/07/1998, 28/10/ 2000.

JORNAL DIARIO CATARINENSE, Florianópolis, edição de 30/07/ 2000.

JORNAL CORREIO DO POVO, Porto Alegre, edição de 21/05/2001. JORNAL FOLHA UNIVERSAL, N. 396, edições de 16/11/1999, 6/ 08/2000.

MAINGUENEAU, Dominique. Termos-chave da análise do discurso. Belo Horizonte, Ed. UFMG, 2000.

MARIANI, Bethania Sampaio Correa. "Sobre um percurso de analise do discurso jornalístico: a revolução de 30", in: INDURSKY, F. et alii (Orgs). Os múltiplos territórios da Análise do Discurso. Porto Alegre, Ed. Sagra Luzzatto, 1999:102-121.

MARIANO, Ricardo. Neopentecostais: sociologia do novo pentecostalismo no Brasil. São Paulo, Ed. Loyola, 1999.

MARIANO, Ricardo. Islâmicos e evangélicos na arena política. 2001, Inédito.

NUNES DA SILVA, Maria Helena. O Príncipe Custódio e a Religião afro-gaúcha. Dissertação de mestrado defendida junto ao PPGAS da Universidade Federal de Pernambuco, 1999.

ORO, Ari Pedro. Avanço pentecostal e reação católica. Petrópolis, Vozes, 1996.

ORO, Ari Pedro. "Pentecôtisme et Politique au Sud du Brésil". In: CORTEN, Andre \& MARY, Andre (org). Imaginaires Politiques et Pentecôtisme: Afrique et Amérique. Paris, Ed. Karthala, 2001:307-320.

ORO, Ari Pedro \& SEMÁN, Pablo. "Os Pentecostalismos nos países do Cone-Sul: panorama e estudos". In: Religião e Sociedade. V. 18, N. 2, 1997:127-150. 
PALMEIRA, Moacir. "Eleição municipal, política e cidadania". In: Tempo e Presença. N. 311, Maio/junho 2000:7-15.

PRANDI, Reginaldo. Os Candomblés de São Paulo. São Paulo, HucitecEdusp, 1991.

REVISTA ISTO É, N. 1623 de 8 de novembro de 2000, entrevista com Lula.

REVISTA EPOCA, N. 142, de 2 de outubro de 2000.

RICHARDSON, Roberto Jarry et Alii. Pesquisa Social, métodos e técnicas. $3^{a}$ ed. São Paulo, Editora Atlas, 1999.

SANCHIS, Pierre. Comentário sobre a Pesquisa. In: FERNANDES et alii. Novo Nascimento. Os evangélicos em casa, na Igreja e na Política. Rio de Janeiro, Mauad, 1998:150-168.

SÉGUY, Jean. "Le clergé dans une perspective sociologique ou que faisons-nous de nos classiques?" In: VI Colloque du C. S. P., Prêtres, pasteurs et rabbins dans la société contemporaine. Paris, Cerf, 1982:11-58.

SÉGUY, Jean. "Charisme de fonction et charisme personnel: le cas de Jean-Paul II'. In: Voyage de Jean-Paul II en France. Paris, Cerf, 1988:11-34.

WEBER, Max. Economie et société. Paris, Plon, 1971. 